\title{
TURISMO E SEGREGAÇÃO SOCIOESPACIAL EM ANGRA DOS REIS: UMA ANÁLISE DA ORGANIZAÇÃO DO ESPAÇO POR MEIO DA GEOINFORMAÇÃO
}

\section{Tourism and Socio-Space Segregation in Angra dos Reis: an analysis of space organization by geoinformation}

\author{
Jéssica Silva Martins \\ Doutoranda do Programa de Pós-Graduação em Geografia - Instituto Geociências - UFRJ \\ martins.jess89@gmail.com \\ Vinicius da Silva Seabra \\ Professor Departamento de Geografia da FFP/UERJ \\ vinigeobr@yahoo.com.br \\ Monika Richter \\ Prof. a do Departamento de Geografia e Políticas Públicas - I. de Educação - UFF \\ mrichter84@hotmail.com
}

Artigo enviado para publicação em 28/09/2019 e aceito em 17/05/2020

DOI: $10.12957 /$ tamoios.2020.45610

\begin{abstract}
Resumo
Na qualidade de um dos 65 destinos indutores do turismo no Brasil, o município de Angra dos Reis RJ, encanta devido às suas belezas naturais. Contudo, o turismo que se consolidou na área continental é fortemente ligado ao turismo de segunda residência, formado por empreendimentos exclusivos com oferta de equipamentos e serviços de luxo. Esses complexos turísticos apropriam-se das áreas nobres da cidade, principalmente através de parceria público-privada, expulsando comunidades tradicionais e contribuindo para o processo de periferização e segregação socioespacial no local. Assim, este estudo visa a análise do processo de ocupação dos chamados condomínios Porto Frade e Porto Marina Bracuhy, e dos setores de entorno, por serem casos emblemáticos do cenário supracitado. Tal análise se fez por meio do processamento dos dados do censo demográfico do IBGE 2010 nesse ambiente e apoiado pela interpretação visual de fotografias aéreas, sendo possível constatar a periferização e a segregação ocorrida, destacando-se fatores econômicos e raciais. Logo, a premissa de um turismo mais justo e equitativo não está sendo observado, exigindo maior compromisso do poder público local e participação da comunidade receptora em prol de maior autonomia e qualidade de vida.
\end{abstract}

Palavras-chave: dados censitários; desenvolvimento turístico sustentável; ordenamento territorial.

\begin{abstract}
As one of the 65 tourism-inducing destinations in Brazil, the city of Angra dos Reis - RJ, enchants due to its natural beauty. However, tourism that has consolidated itself in the continental area is strongly linked to tourism of second residence, formed by exclusive enterprises offering luxury equipment and services. These tourist complexes take advantage of the noble areas of the cities, mainly through public-private partnership, expelling traditional communities and contributing to the process of peripheralization and socio-spatial segregation in the place. Thus, this study aims to analyze the process of occupation of the so-called Porto Frade and Porto Marina Bracuhy condominiums, and the surrounding sectors, as they are emblematic cases of the above scenario. This analysis was made through the processing of IBGE 2010 census data in this environment and supported by the visual interpretation of aerial photographs, highlighting economic and racial factors. Therefore, the premise of a fairer and more equitable tourism is not being observed, demanding greater commitment from the local public power and participation of the receiving community in favor of greater autonomy and quality of life.
\end{abstract}

Key words: census data; sustainable tourism development; land use planning. 


\section{Introdução}

O município de Angra dos Reis, localizado ao Sul do Estado do Rio de Janeiro, possui uma diversidade de atividades econômicas que contribuem para a formação da identidade social histórico local. Dentre essas, destaca-se as atividades turísticas devido seu poder de territorialização, e de impactar diferentes âmbitos no município, como o social, econômico, ambiental, cultural e político. Assim, este estudo tem como objeto a segregação socioespacial na cidade de Angra dos Reis em função do desenvolvimento do turismo, especialmente em relação à implantação de dois empreendimentos turísticos, Porto Frade e Porto Marina Bracuhy, que são estudos de caso deste trabalho.

Angra dos Reis é um dos 65 destinos indutores do turismo, conquistando esse título principalmente devido as suas belezas naturais. Contudo, o turismo que se formou no continente é aquele voltado para as pessoas com maior poder aquisitivo, composto por casas de segunda residência, hotéis de grande porte, condomínios de luxo, marinas e até complexos turísticos englobando várias das construções citadas.

Por conseguinte, os investimentos gerados para o desenvolvimento desse tipo de turismo ocorreram de maneira exógena, por iniciativa do poder Estatal e do capital privado que se apoderou de grandes extensões de terra e das características naturais da região para o desenvolvimento de "projetos turísticos" (ABREU, 2005).

Entretanto, essa apropriação do espaço contribuiu para a formação de uma paisagem elitista no local, em razão da intensa especulação imobiliária que valorizou os locais de maior acessibilidade e de grande beleza cênica, principalmente os litorâneos, resultando em processos de expropriação da população nativa, como os caiçaras, que se viram obrigados a abandonar suas terras, sua cultura e sua fonte de renda, muitas vezes, para habitar áreas de risco, como topos de morros e encostas, sujeitos a processos de deslizamento de terra e enchentes ou locais insalubres devido à poluição e a falta de saneamento básico, contribuindo, desse modo, para o processo de segregação socioespacial. (ABREU, 2005; GÓIS, 2009; CPDA-UFRRJ, 2015).

Outros impactos percebidos são os relacionados ao meio ambiente devido à degradação do patrimônio ambiental e perda da biodiversidade, como a supressão da vegetação nativa, aterro dos manguezais, destruição de restingas, abertura de canais navegáveis, poluição das águas e outros.

Diante do exposto, percebe-se a necessidade de investigação dos rendimentos da atividade turística em Angra dos Reis que, perante os impactos mencionados, se afasta das premissas do turismo sustentável que deve assegurar uma distribuição justa de custos e benefícios, sendo um vetor de desenvolvimento local, contribuindo para a conservação e preservação do patrimônio natural e histórico cultural.

Por isso, torna-se essencial compreender o processo de ocupação e consumo do espaço, em razão da instalação dos complexos turísticos-imobiliários Porto Frade e Porto Marina Bracuhy, assim como, as transformações e reorganização espacial dos setores de influência desses empreendimentos, que neste estudo, são analisados por meio da modelagem de dados apoiado pelo uso de um dos sistemas de informação geográfica (SIG), voltados para o armazenamento, processamento e a análise de dados georreferenciados. Tais dados são referentes ao censo do IBGE 2010, cujo análise posterior é apoiada por fotografias aéreas não georrefenciadas e imagens de satélites disponibilizadas no programa Google Earth do município. Esses dados, manipulados de maneira integrada, constituem-se em elementar mecanismo de análise e monitoramento do desempenho da atividade turística e seus efeitos no espaço em análise.

Outrossim, é a formação de um arcabouço de informações de fácil compreensão, principalmente devido à produção de mapas temáticos, que orientam a tomada de decisão 
de agentes sociais envolvidos com o turismo, principalmente a comunidade receptora, atribuindo-lhe maior autonomia para gerir uma atividade que impacta significativamente seu local de moradia.

\section{Capital Imobiliário e Segregação Socioespacial}

Para o desenvolvimento deste estudo e compreensão dos aspectos que envolvem o turismo em Angra dos Reis foi imprescindível a contribuição de determinados autores, que através de suas ideias principais, nortearam o desdobramento do presente trabalho.

Segundo o Código de Ética Mundial para o Turismo, os princípios que o rege são aqueles anunciados pelas Nações Unidas durante a Rio-92, que envolve harmonizar de maneira sustentável a proteção do meio ambiente, o desenvolvimento econômico e a luta contra a pobreza. Citando alguns de seus artigos tem-se: Contribuição do turismo para o entendimento e o respeito mútuo entre homens e sociedades; $\mathrm{O}$ turismo, fator de desenvolvimento sustentável; O turismo, fator de aproveitamento e enriquecimento do patrimônio cultural da humanidade; O turismo, atividade benéfica para os países e comunidades de destino; Direito ao turismo e outros (OMT, 2000).

Ao aplicar esses princípios éticos para a escala local, especificamente, em relação à cidade de Angra dos Reis, nota-se certo desajuste, já que o turismo que se desenvolve na região, contribuiu diversas vezes para a expropriação da população nativa e, consequentemente, descaracterização de sua cultura; para a degradação da biodiversidade local, principalmente pelo aterro de manguezais; investimento em resorts e condomínios fechados que tolhe a inter-relação entre visitante e comunidade receptora.

Assim, Abreu (2005) acredita que por meio da justificativa do desenvolvimento do turismo em Angra, inicialmente impulsionada por investimentos estatais e posteriormente pelo poder municipal, o capital imobiliário se apropriou de grandes extensões de terra e dos recursos cênicos e ambientais da região de maneira predatória, gerando conflitos com grupos sociais que buscam no turismo uma alternativa de desenvolvimento sustentável.

Para o mesmo autor, aos conflitos ambientais agregam-se também os sociais "deflagrados principalmente pelas novas possibilidades de acumulação, o que significa também o acirramento das demandas sociais, uma vez que para os grupos sociais excluídos desse processo sobram os terrenos menos propícios à ocupação" (ABREU, 2005, p. 40).

Segundo Milton Santos, em sua obra "A Urbanização Brasileira", as cidades fazem parte de um elo maior, a serviço das atividades com dimensão nacional, ou seja, as grandes empresas e o Estado. Por isso, recebem infraestrutura adequada a essa vocação "nacional". O Estado, detentor quase monopolista das reflexões sobre o planejamento do território, prioriza os investimentos a favor das grandes corporações, como investimentos em acessibilidade, transporte e comunicação, negligenciando a população local e as pequenas empresas, contribuindo para concentração de riquezas e consequente aumento da pobreza (SANTOS, 1993).

Milton Santos (1993) relata que o próprio poder público é criador da escassez, valorizando determinadas áreas, acaba por estimular a especulação imobiliária e fomentar a produção de espaços vazios, empurrando a população mais pobre para as periferias, sendo esta, incapaz de pagar pelos altos preços das terras.

Todo o melhoramento numa área pobre faz dela o teatro de conflitos de interesses com as classes médias em expansão, para não falar das classes altas. A rapidez com que se instala o processo de verticalização tem como paralelo um processo de suburbanização. Como o número de pobres se expande ainda mais depressa, há pressão pela terra também 
entre os pobres e o resultado é uma expansão geográfica da cidade, periferização que se dá com a criação de espaços vazios, graças ao modelo rodoviário. É um equívoco pensar que problemas urbanos podem ser resolvidos sem a solução da problemática social. É esta que comanda e não o contrário (SANTOS, 1993).

Nesse contexto, na obra de Roberto Lobato Correa, O Espaço Urbano, o autor relata sobre o poder que o Estado detém em relação à organização e ocupação do território, que se legitima através da elaboração de diversas leis vinculadas ao uso do solo, como a lei de zoneamento e o código de obras. A implantação de serviços públicos a qual é provedor é distribuída de maneira espacialmente desigual, gerando diversos conflitos de interesse, já que o Estado privilegia a classe dominante (CORREA, 1989).

Logo, a atuação do Estado vai de encontro à reprodução da sociedade capitalista, assim como, ao processo de acumulação e a reprodução das classes sociais. Com isso, cria mecanismos que levam a segregação residencial, como por exemplo, a diferença no valor do imposto territorial e predial, que afeta o preço das terras e dos imóveis, no qual os grupos de maior poder aquisitivo, residem em imóveis mais caros e melhor localizados, incidindo consequentemente, na segregação social (CORREA, 1989).

Assim, a classe dominante e algumas de suas frações possuem o poder de autossegregação, já que são capazes financeiramente de escolher onde residir, detendo para si, as melhores porções de terra. Esta segregação materializa-se, como por exemplo, pelos condomínios fechados. Em suma, ao mesmo tempo, em que a classe dominante controla o mercado de terras, induz a população mais pobre a habitar locais menos valorizados e periféricos, garantindo assim, a divisão social do trabalho e as relações sociais de produção, fator denominado pelo autor de segregação imposta (CORREA, 1989).

Com os fatos acima expostos, percebe-se como o turismo em Angra dos Reis, manipulado principalmente pelo mercado imobiliário, contribui para o aumento do processo de segregação socioespacial no município, se afastando assim, do Código de Ética Mundial para o Turismo.

Contudo, para Castoriadis (1982) toda determinação, que é uma criação, pode ser preterida por novas criações, substituindo as primeiras. Em seu livro, "A Instituição Imaginária da Sociedade", o autor afirma que as significações imaginárias sociais podem ser rompidas, que o imaginário instituinte pode ser questionado, enfraquecido, criando outro tipo de ser, outra subjetividade. Assim, a sociedade busca sua autonomia, através do poder instituinte da coletividade.

Logo, é imprescindível a necessidade de um novo paradigma em relação ao planejamento e organização do turismo em Angra dos Reis, sendo o monitoramento dele igualmente importante. Reforça-se, a ideia de planejamento holístico e participativo, garantindo maior poder de decisão a todos os grupos sociais envolvidos com a atividade turística, sendo possível dessa maneira, evitar os possíveis interesses próprios daqueles que geralmente detém o poder, e lutar por um turismo com base local, mais igualitário, em prol de maior autonomia social.

Para tanto, o uso de produtos cartográficos e dos sistemas de informação geográfica são fundamentais para essas funções, na medida em que auxiliam no processo de tomada de decisão.

Assim, no livro Introdução à Ciência da Geoinformação, é abordado os conceitos básicos das geotecnologias, apresentando-as com expressivo potencial para suprir as necessidades de informações adequadas acerca do processo de tomada de decisão sobre problemas urbanos, rurais e ambientais. Além de ser baseado em tecnologias de custo relativamente baixo em que o conhecimento seja adquirido a nível local (CÂMARA \& DAVIS, 2001). 


\section{Metodologia}

Como forma de aproximar as premissas teórico-metodológicas deste estudo do seu objeto de pesquisa, determinadas etapas foram necessárias, como o levantamento de dados bibliográficos, abrangendo assuntos como a produção do espaço urbano, justiça ambiental, conflitos socioambientais, informações sobre o turismo em Angra dos Reis, geotecnologias etc. Segundo Silva e Zaidan (2004, p. 189 e 190):

Para tratar de situações (ou fenômenos) que ocorrem no espaço, necessita-se de informação espacializada e integrada que subsidie a tomada de decisão. A possibilidade de processar geograficamente informação confiável, precisa e rapidamente acessível, para elaboração de planos e estratégias necessários à gestão do território municipal, compatíveis com as características particulares de cada sociedade e do espaço por ela ocupado ou produzido, é, sem dúvida, a contribuição maior da ciência da geoinformação.

Essas tecnologias tornam-se cada vez mais importantes, pois devido as suas técnicas para o tratamento da informação são capazes de propiciar melhor conhecimento do espaço e da sociedade, assim como a relação entre os mesmos e disponibilizá-las em forma de mapas, relatórios e tabelas, o que se constitui em um poderoso alicerce para análise e subsídio a tomada de decisão.

Os mapas temáticos elaborados neste trabalho foram gerados a partir de dados do Censo 2010 do IBGE e anexados a malha digital da área de estudo no software ArcGis 9.3, disponibilizado pelo Grupo de Estudos Dinâmicas Ambientais e Geoprocessamento da UERJ, campus São Gonçalo. Os dados utilizados segundo as informações do censo demográfico 2010 do IBGE seguem no quadro 01:

Quadro 01: Variáveis selecionadas

\begin{tabular}{|c|c|}
\hline DESCRIÇÃO DA VARIÁVEL & CONSTRUÇÃO DA VARIÁVEL \\
\hline \multicolumn{2}{|l|}{ Pessoas residentes } \\
\hline Raça branca & $\begin{array}{l}\Sigma \text { amarelos, brancos, indígenas, pardos } \mathrm{e} \\
\text { pretos } * \text { brancos } / 100\end{array}$ \\
\hline Raça “outros" & $\Sigma$ amarelos, indígenas, pardos e pretos \\
\hline \multicolumn{2}{|l|}{ Pessoas com $1 / 2$ a 1 salário mínimo } \\
\hline \multicolumn{2}{|l|}{ Pessoas com mais de 10 salários mínimos } \\
\hline $\begin{array}{l}\text { Domicílios particulares com esgoto a céu } \\
\text { aberto }\end{array}$ & $\begin{array}{l}\text { Domicílios particulares permanentes próprios } \\
+ \text { alugados + cedidos com esgoto a céu aberto }\end{array}$ \\
\hline $\begin{array}{l}\text { Domicílios particulares com lixo acumulado } \\
\text { nos logradouros }\end{array}$ & $\begin{array}{l}\text { Domicílios particulares permanentes próprios } \\
+ \text { alugados + cedidos com lixo acumulado nos } \\
\text { logradouros }\end{array}$ \\
\hline Aglomerados subnormais & \\
\hline
\end{tabular}

Fonte: própria

As fotografias aéreas não georreferenciadas, utilizadas em apoio a interpretação da situação pretérita da ocupação, foram disponibilizadas pela prefeitura de Angra dos Reis em 2015 e são referentes aos anos de 1966, 1979, 1987 e 1991, abrangendo as áreas dos bairros Porto Frade, Frade, Grataú, Praia do Recife, Gamboa do Bracuí, Ilha do Jorge, 
Santa Rita do Bracuí, Bracuí, Sertão do Bracuí e Itanema, expostas abaixo. Já as imagens de satélites atuais foram analisadas por meio da plataforma Google Earth.

Em suma, fazer uso de recursos cartográficos como instrumento de planejamento, gestão e monitoramento do turismo, é uma maneira eficaz de possibilitar uma real participação popular no processo decisório da atividade, visto a informação resultante ser de fácil compreensão, principalmente em relação aos mapas temáticos. Desta forma, o presente trabalho busca analisar os processos de ocupação das áreas dos empreendimentos Porto Frade e Porto Marina Bracuhy e a segregação socioespacial decorrente, possivelmente, da instalação dos empreendimentos citados a partir do processamento e modelagem dos dados do IBGE.

\section{Área de Estudo}

Reconhecida por sua beleza cênica, o município de Angra dos Reis localizado ao sul do estado do Rio de Janeiro, possui no turismo uma de suas principais atividades econômicas. Situada também na região turística da Costa Verde, juntamente a Paraty, Mangaratiba, Rio Claro e Itaguaí, sendo muitas vezes exposta pela mídia, como por meio de novelas, como local paradisíaco e de luxo, frequentada por celebridades e por pessoas de alto poder aquisitivo.

Apresenta-se no mapa 01 a localização da área de estudo e dos condomínios Porto Frade e Porto Marina Bracuhy no município de Angra dos Reis, inserido na região turística da Costa Verde.

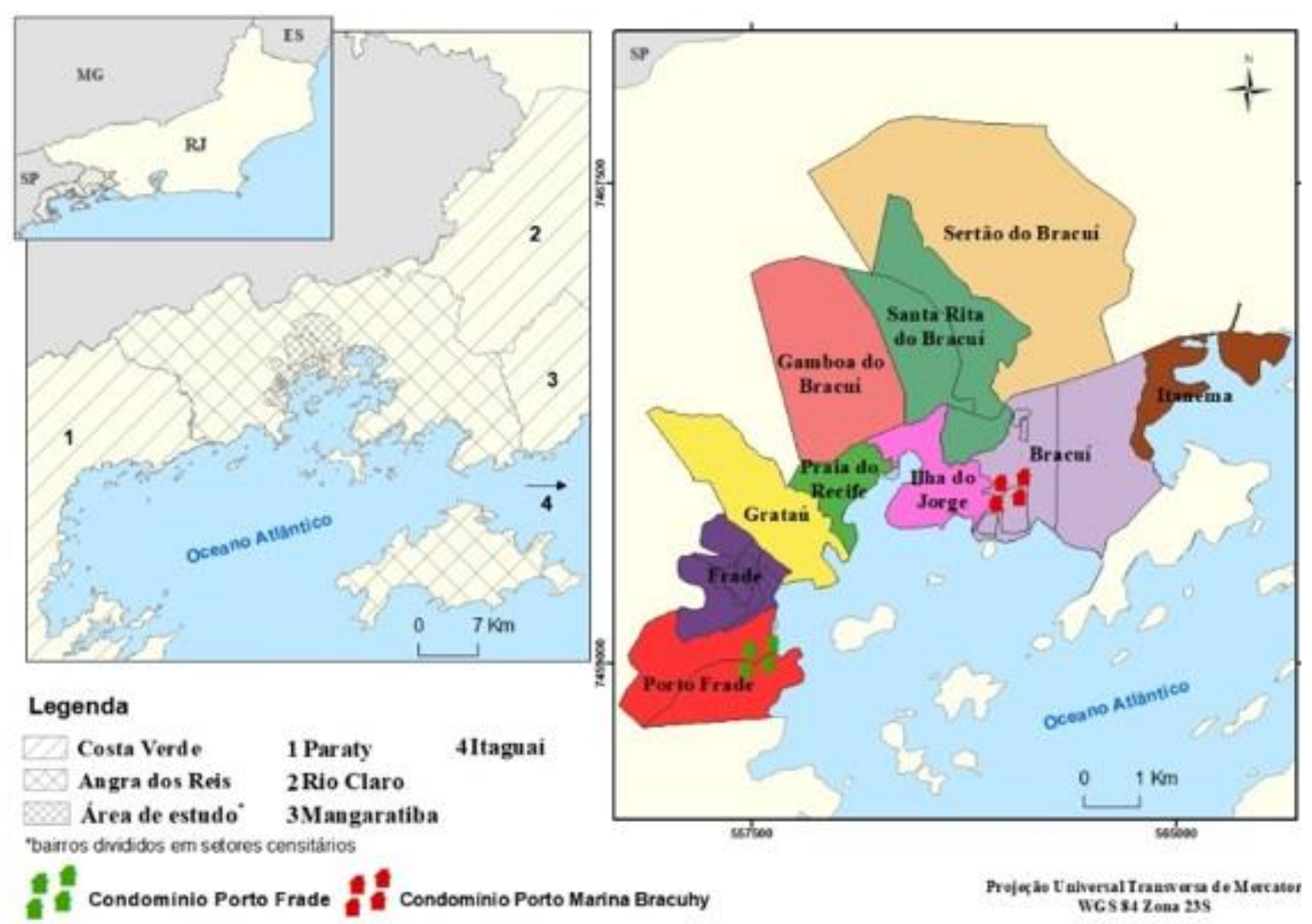

Mapa 01: Localização do município de Angra dos Reis e dos condomínios em análise.

Fonte: Própria, 2019 


\section{Resultados e Discussões}

Este tópico trata especificamente dos dados e das análises referentes ao processo de ocupação das áreas dos empreendimentos Porto Frade e Porto Marina Bracuhy e do processo de segregação socioespacial decorrente, possivelmente, da instalação dos empreendimentos citados.

As fotografias aéreas abaixo (figura 01) datam de 1966, 1979 e 1987 e representam a área do Porto Frade e o entorno imediato como o bairro do Frade, Grataú e Praia do Recife. Na primeira data é notório determinadas intervenções antrópicas na região, como a construção da rodovia Rio-Santos que cruza toda a área, inaugurada na década de 1970 e as áreas de gramíneas que avançam sobre as áreas de florestas. Após 13 anos, em 1979 percebe-se a abertura dos canais navegáveis do Porto Frade, ainda sem qualquer adensamento populacional, sendo a ocupação rarefeita. Contudo, num período de 08 anos (1987) já se identifica considerável modificação no bairro do Frade com expressivo adensamento de casas, a maioria próxima à rodovia BR-101. Atenção também para o aumento de áreas desmatadas nas margens do Rio Grataú após a BR-101, assim como, em grande extensão do bairro do Grataú e Praia do Recife.

Pode-se supor o aumento populacional na área do Frade por 03 motivos: reserva de mão de obra para os empreendimentos do Porto Frade e da Eletronuclear (Angra 1 e Angra 2, cujas obras iniciaram nos anos 80) e também, devido a expropriação da população nativa nas orlas, agora ocupada pelos empreendimentos citados. É notório que a ocupação dessa área ocorreu sem apoio de infraestrutura pública, estimulada possivelmente pelos investimentos em prol do Porto Frade, como a abertura BR-101, energia elétrica e outros.

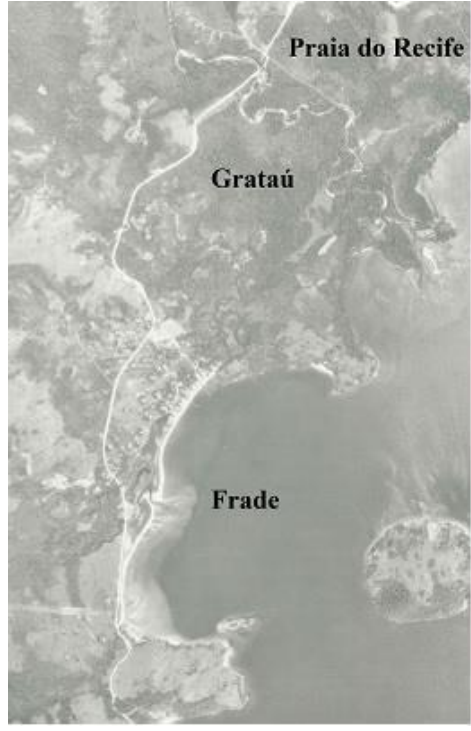

(a) Frade 1966

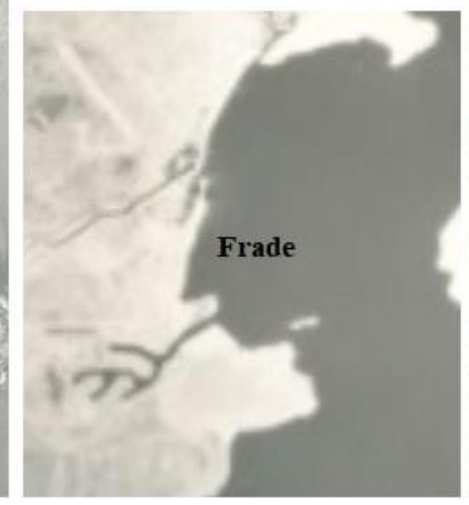

(b) Frade 1979

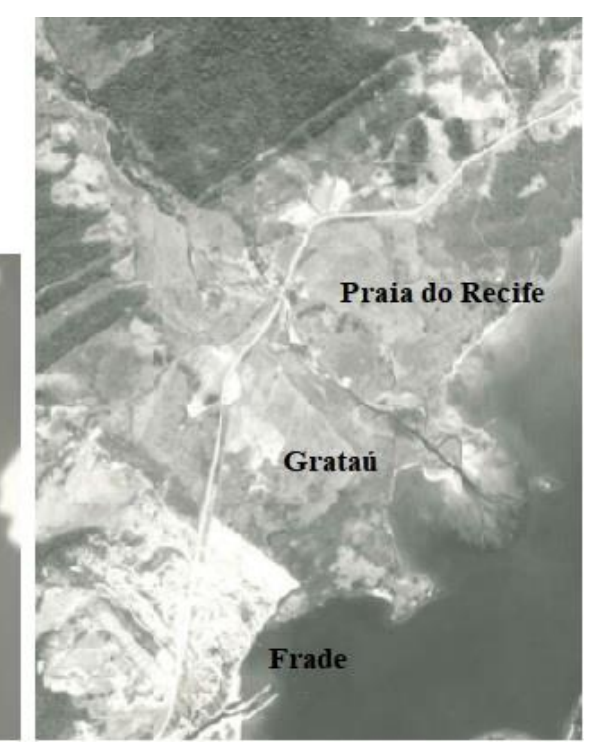

(c) Frade 1987

Figura 01: (a) Fotografia aérea Frade (1966) (b) Frade (1979) (c) Frade (1987). Fonte: Prefeitura de Angra dos Reis

No período de 1991 a 2019 (figura 02) no que concerne as alterações na cobertura da terra das áreas do Porto Frade, Frade, Grataú e Praia do Recife, nota-se que a ocupação no Porto Frade ocorreu de maneira mais organizada e menos densa, com a presença de iates próximos a orla. Já a densidade populacional do Frade é significativamente maior, com construção de casas avançando sobre as áreas de floresta. 
Enquanto as residências do Porto Frade são de luxo, com infraestrutura e saneamento básico adequados; as residências do bairro do Frade são em sua maioria mais simples, sendo que algumas localidades sofrem significativa deficiência no abastecimento de água e saneamento básico ${ }^{1}$. $\mathrm{O}$ adensamento também é maior, e muitas residências foram construídas nas encostas dos morros e avançam sobre eles, evidenciado o possível risco ambiental a que estão expostas. Ademais a expansão do bairro do Frade cresce em direção à floresta, conhecida como Sertãozinho do Frade, assim como, de maneira menos expressiva, surge uma ocupação rarefeita atrás do Porto Frade, depois da BR-101.

Ao passo que a população com menor poder aquisitivo parece avançar sobre as áreas de floresta e sobre os morros, os bairros do Grataú e Praia do Recife seguem aparentemente inalterados, pertencentes a um único proprietário.

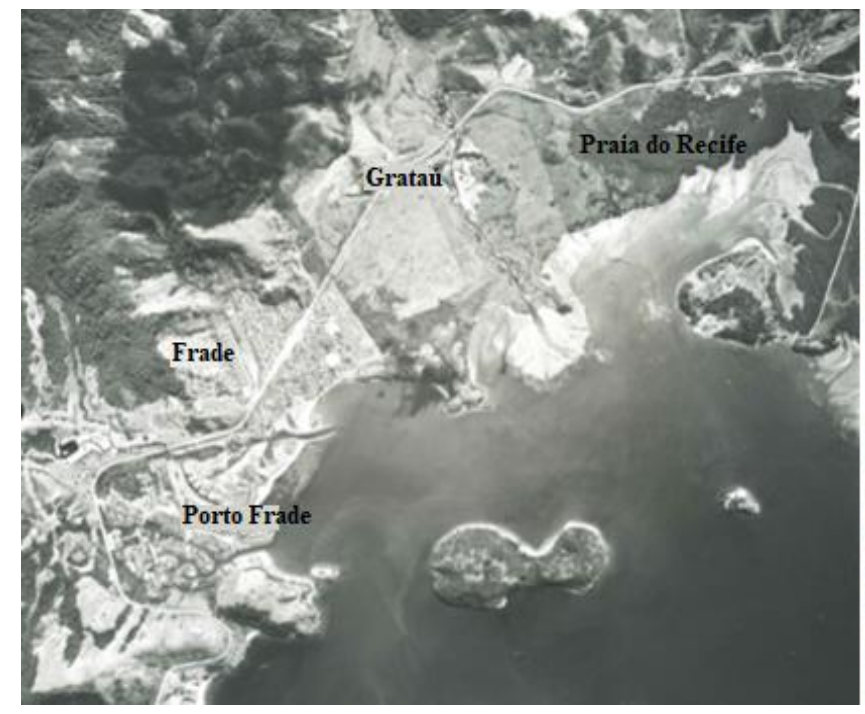

(a) Frade 1991

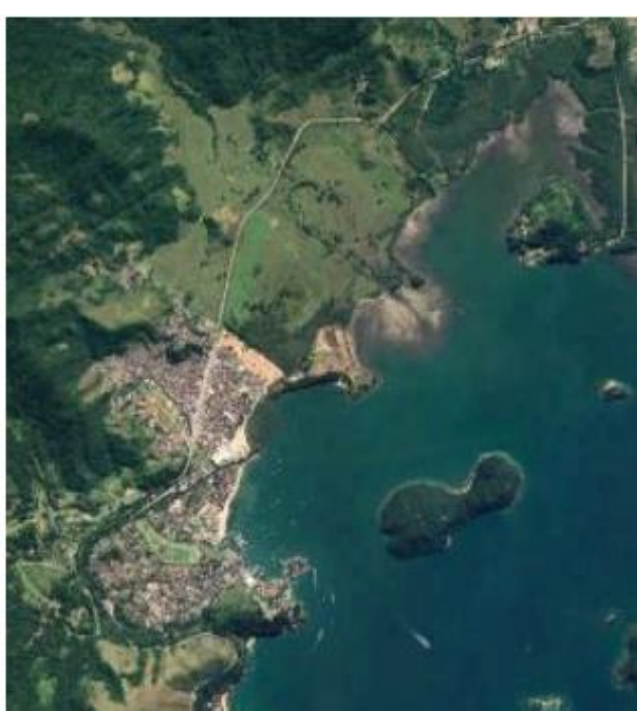

(b) Frade 2019

Figura 02: (a) Fotografia aérea Frade (1991) (b) Frade (2019). Fonte: Prefeitura de Angra dos Reis e Google Earth

As análises a seguir referrem-se ao Porto Marina Bracuhy e seu entorno imediato como Ilha do Jorge, Santa Rita do Bracuí, Bracuí e outros, expondo fotografias áreas de 1966 e 1987 (figura 03). Em 1966 são perceptíveis as áreas desmatadas e o curso do Rio Bracuí que permanece inalterado. Em 1979 nota-se a abertura dos canais navegáveis do Porto Marina Bracuhy e consequente alteração do curso do Rio Bracuí ao lado. Nesta área também não é possível apontar adensamentos populacionais. 


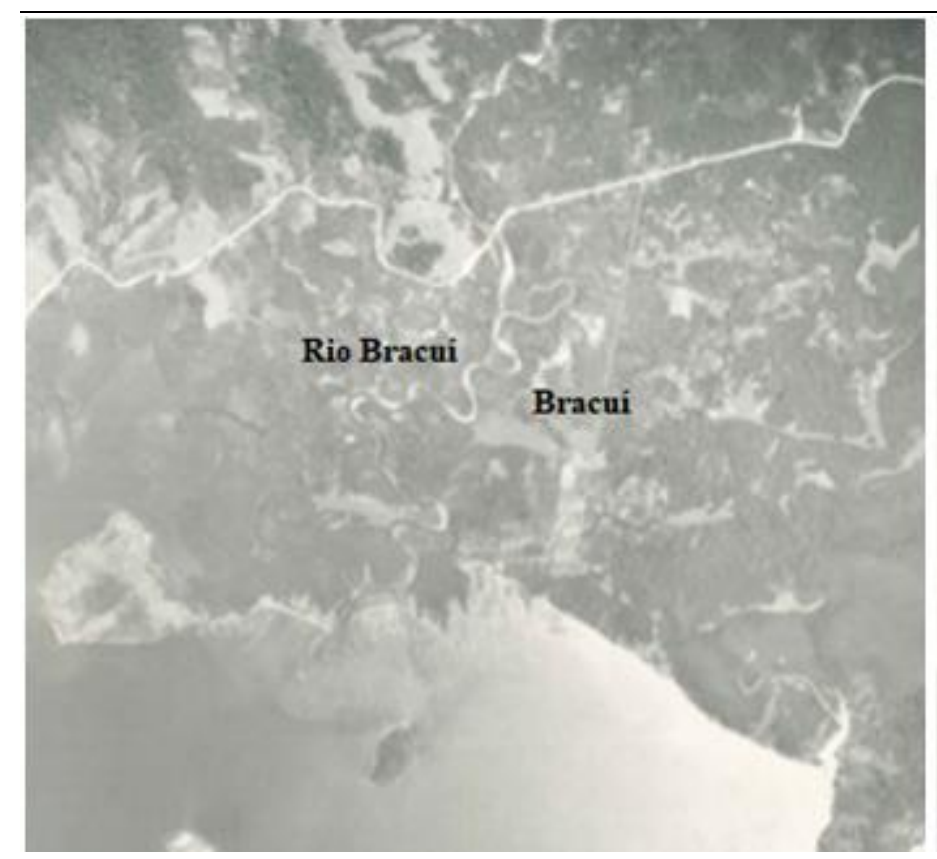

(a) Bracuí 1966

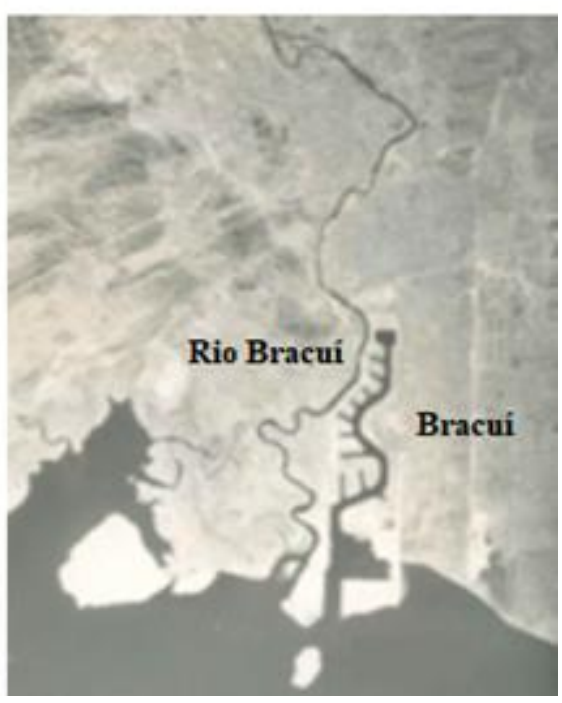

(b) Bracuí 1987

Figura 03: (a) Fotografia aérea Bracuí (1966) (b) Bracuí (1987). Fonte: Prefeitura de Angra dos Reis

No que concerne a fotografia área de 1991 e a imagem do Google Earth de 2019 (figura 04), percebe-se em 1991 maior ocupação em torno do canal navegável Porto Marina Bracuhy e ao lado direito do empreendimento a vegetação que ainda ocupava a maior parte da área. Algumas ocupações rarefeitas são notórias próximas ao empreendimento Porto Marina Bracuhy, no Bairro Bracuí, Santa Rita do Bracuí e Gamboa do Bracuí. Também é visível o aumento das áreas desmatadas em determinados morros em Santa Rita do Bracuí, Gamboa do Bracuí e próximo ao curso do Rio Bracuí.

Em 2019 observa-se o aumento populacional no bairro de Santa Rita do Bracuí que se concentra próximo à rodovia BR-101 e de forma menos expressiva em direção ao interior, seguindo para a área de floresta. De acordo com o site Mapa de Cultura (2016), no local existe o Quilombo Santa Rita do Bracuí, que mantém suas tradições africanas.

O bairro do Bracuí também se destaca em relação ao aumento populacional, principalmente na área do Porto Marina Bracuhy ao redor do canal navegável, e ao lado direito do empreendimento, que cresceu consideravelmente. Neste local existe o condomínio Morada do Bracuhy entregue no ano de 2004, as vítimas das chuvas de 2002 (PREFEITURA DE ANGRA, 2013). Segundo o site AngraNews, em julho de 2012, uma comissão de moradores do condomínio Morada do Bracuhy realizou manifestação solicitando ao poder público, soluções para os problemas sucessivos de alagamentos por falta de infraestrutura e saneamento básico. A mesma reportagem relata que a falta d'água também é um problema entre os moradores locais (ANGRANEWS, 2010). 


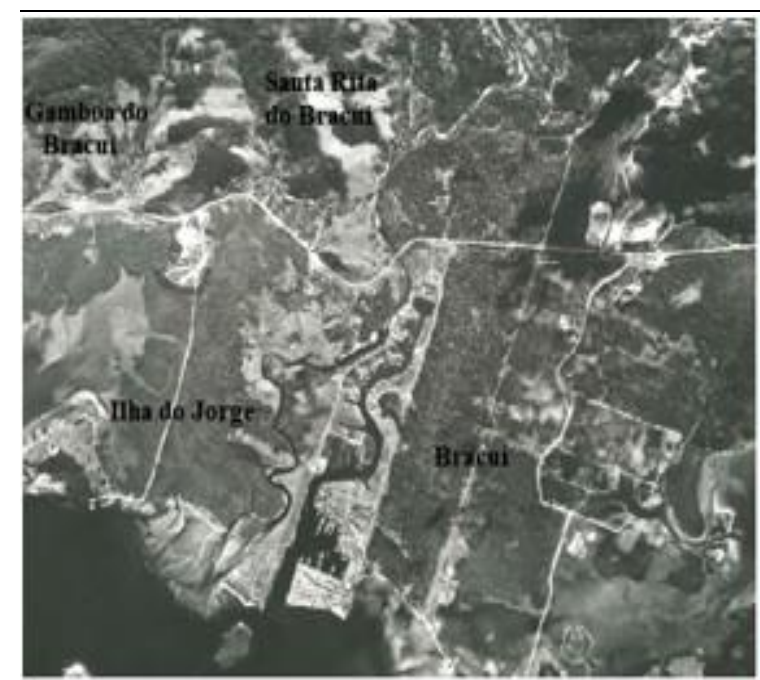

(a) Bracuí 1991

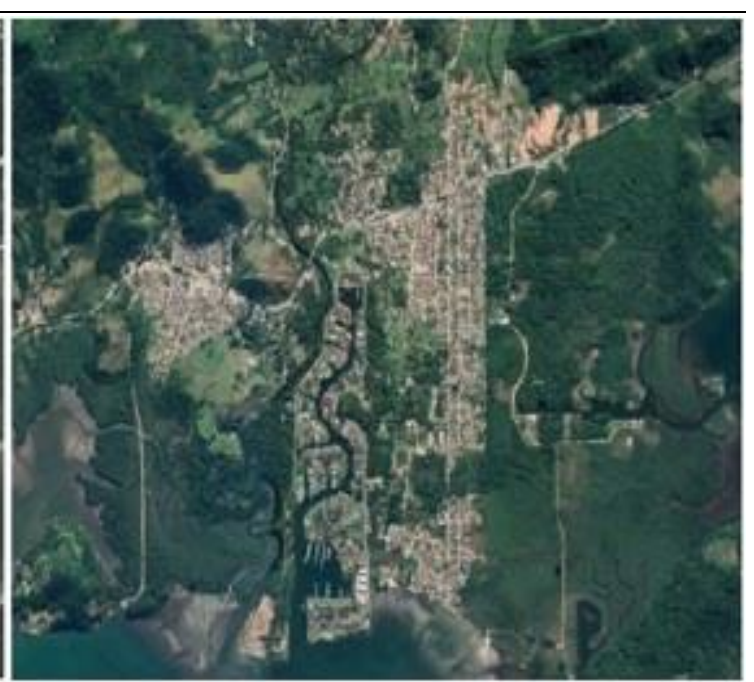

(b) Bracuí 2019

Figura 04: (a) Bracuí (1991) (b) Bracuí (2019). Fonte: Prefeitura de Angra dos Reis e Google

Earth

No bairro de Itanema, existe um contingente populacional apenas ao redor da orla com a presença da Rio Marina Yacht Collection e do Condomínio Porto Marisco. É perceptível a diferença no tocante à infraestrutura e as residências ofertadas pelos condomínios Porto Bracuhy e Porto Marisco das que são construídas ao lado do condomínio Bracuhy, como constatado na figura 05. As dos condomínios são consideravelmente maiores, algumas com piscinas e sua própria vaga molhada para barcos. Nota-se também os iates e outros tipos de embarcações próximos as casas.

(a) Bracuhy

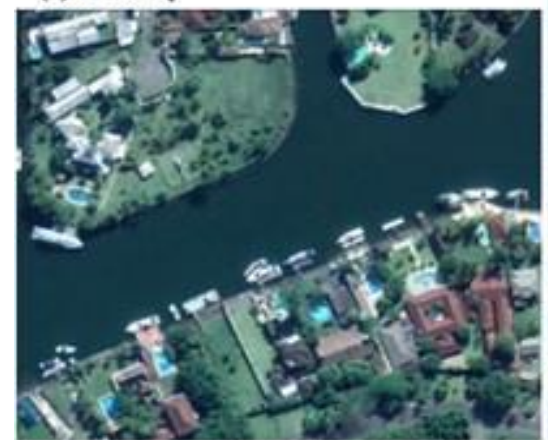

(b) Itanema

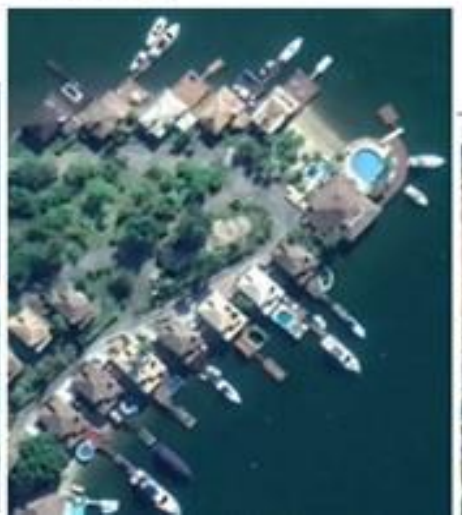

(c) aglomerado de casas

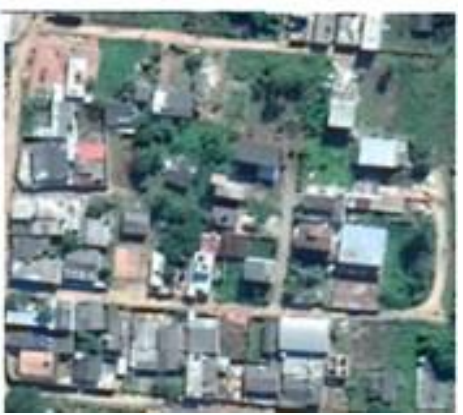

Figura 05: Detalhe dos imóveis dos condomónios Bracuhy (a) e Itanema (b) em relação ao aglomerado de casas ao lado do condomíno Bracuhy (c).

Deve-se evidenciar o impacto sobre manguezais nas áreas dos dois empreendimentos analisados e seu entorno, causando intenso desmatamento e consequente perda de biodiversidade, negligenciando o fato dos manguezais serem protegidos por leis ambientais desde 1965. De acordo com Moscatelli (2001 apud Eletronuclear, 2005) os manguezais de Angra dos Reis foram reduzidos a 60\% da área originalmente ocupada. $\mathrm{O}$ quadro 02 destaca a situação dos manguezais em algumas localidades da área de estudo. 


\begin{tabular}{|c|l|}
\hline \multicolumn{2}{c}{ Quadro 02: Situação dos manguezais na área de estudo } \\
\hline LOCALIDADE & \multicolumn{1}{c|}{ SITUAÇÃO DOS MANGUEZAIS } \\
\hline Gamboa do Bracuí & $\begin{array}{l}\text { Parcialmente aterrado pela instalação de loteamento seccionado } \\
\text { pela abertura da rodovia BR-101, que vem sendo assoreado em } \\
\text { virtude da saibreira situada a montante da rodovia. }\end{array}$ \\
\hline Itanema & $\begin{array}{l}\text { Parcialmente aterrado para a instalação dos empreendimentos } \\
\text { imobiliários Porto Itanema, Porto Marisco e de estaleiro, porém } \\
\text { ainda expressivo. }\end{array}$ \\
\hline Bracuí/Cansado & $\begin{array}{l}\text { Um dos maiores mangues do município de Angra dos Reis, } \\
\text { parcialmente desmatado, degradado e aterrado, visando a } \\
\text { instalação de grande loteamento e marina. }\end{array}$ \\
\hline Bracuí & $\begin{array}{l}\text { Completamente aterrado para instalação de loteamento e marina } \\
\text { de mesmo nome. }\end{array}$ \\
\hline Saco do Bracuí & $\begin{array}{l}\text { Parcialmente impactado pela construção de via de acesso ligando } \\
\text { a BR-101 ao loteamento da Ilha do Jorge; apresenta sinais de } \\
\text { recuperação natural, mas com alteração de suas comunidades } \\
\text { vegetais. }\end{array}$ \\
\hline Frade & $\begin{array}{l}\text { Completamente aterrado para a instalação de dependências } \\
\text { hoteleiras e do loteamento associado. }\end{array}$ \\
\hline
\end{tabular}

Fonte: ELETRONUCLEAR, 2005.

A seguir apresenta-se as diferenças entre os setores onde se encontram os dois empreendimentos estudados e os demais setores, a partir de suas representações cartográficas, como forma de analisar se existe segregação racial e presença de aglomerados subnormais na localidade de estudo.

Destaca-se que nos mapas existem dois setores omitidos no Bracuí, devido à falta de informações, já que essas não foram divulgadas pelo IBGE. Também, dá-se ênfase, aos setores onde se encontra o empreendimento Porto Marina Bracuhy, devido partes do empreendimento estar compreendido no mesmo setor do aglomerado de casas mais simples ao lado direito, entre elas, a habitação social, condomínio Morada do Bracuhy.

\section{Condicionantes Socioeconômicas a partir do Censo IBGE 2010}

O quantitativo de residentes (mapa 02) no setor do condomínio Porto Marina Bracuhy e entorno imediato e o bairro Sertão do Bracuí destacam-se com o maior número de pessoas residentes entre 1384 a 2165 pessoas. Porém, o Sertão do Bracuí é consideravelmente maior em extensão territorial e encontra-se em área rural.

Os bairros com 903 a 1384 residentes são 2 setores de Santa Rita do Bracuí, 1 do Bracuí e 6 setores do bairro do Frade. Com valores médios entre 903 a 474 localizam-se 6 setores do bairro do Frade, 1 do Santa Rita do Bracuí e o bairro Itanema, ressaltando que os setores do Frade são de pequena extensão territorial.

Com os dois intervalos mais baixos entre 474 a 29 residentes tem-se os bairros Porto Frade, Grataú, Praia do Recife, Ilha do Jorge, Gamboa do Bracuí, 02 setores do Frade e 2 do Bracuí, onde se situa o condomínio Porto Marina Bracuhy. 


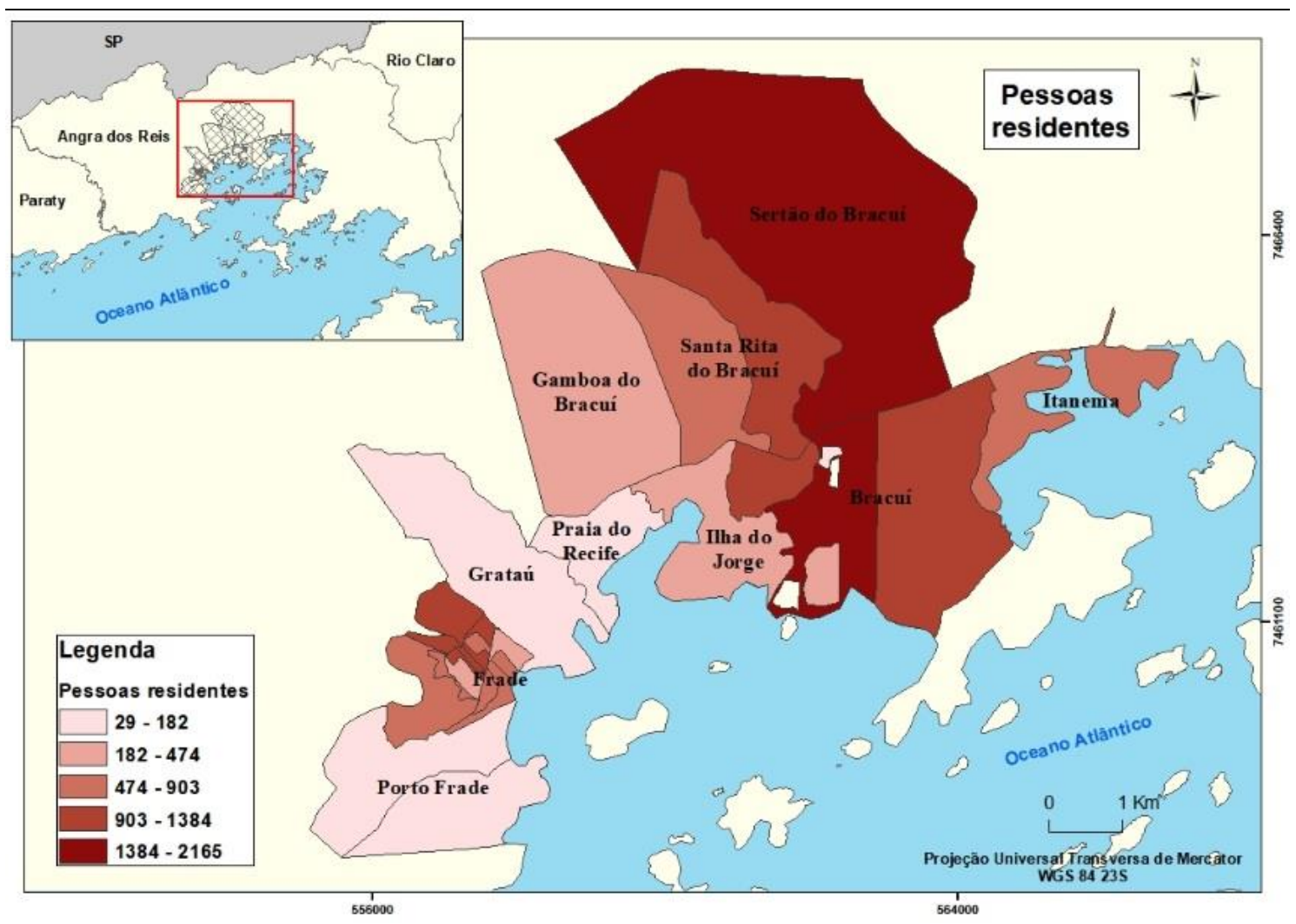

Mapa 02: Pessoas residentes - Angra dos Reis/RJ. Fonte: própria

Os mapas abaixo (mapas 03, 04, e 05) relacionam a quantidade de pessoas que ganham mais de 10 salários mínimos com a raça a qual pertentem, divididos entre brancos e outros, no qual outros correspondem ao somatório das raças parda, amarela, indígena e preta. Como alguns setores são pequenos, para ter uma melhor visualização, eles foram analisados de maneira separada como segue:

O mapa 03 destaca o bairro Porto Frade, onde se situa o empreendimento turístico Porto Frade. Percebe-se que um dos setores do bairro possui o maior número de pessoas com mais de 10 salários mínimos entre 13 e 26 pessoas, lembrando que em 2010, ano do censo, o valor do salário mínimo era de $\mathrm{R} \$ 510,00$, ou seja, pessoas que recebiam mais de $\mathrm{R} \$ 5.100,00$. Através da interpretação do mapa também se nota que mais da metade da composição racial do setor são de pessoas brancas. Já o outro setor possui o terceiro maior intervalo entre 1 a 5 pessoas com mais de 10 salários mínimos e aproximadamente metade de sua composição racial é de brancos.

Entretanto, nesse bairro, encontra-se o Porto Frade Imovéis, que oferece imovéis com localização canal, costeira, golfe, ilhas e praia. Segundo o site Zap imóveis, uma casa administrada pela corretora Porto Frade Imovéis, com 06 quartos e 06 suítes, possui valor aproximado de venda de $\mathrm{R} \$ 5.000,000$. O site também disponibiliza valores de outras casas, administradas também por outras corretoras, com valores que variam de $\mathrm{R} \$$ 800,000 a R \$15.000,00 (ZAPIMÓVEIS, 2016).

No local também existe a YachtBrasil, grupo náutico que comercializa os luxuosos barcos Sea Ray, Cabo Yachts, Sacs Marine, Raptor, Azimut Grande Yachts e Benetti Yachts e uma sede do Iate Clube de Santos.

Logo, é notório que para manter um padrão de vida com os valores supracitados é necessário possuir renda muito acima de $\mathrm{R} \$ 5.100,00$. Contudo, quantidade considerável de imóveis nesse bairro é utilizada como segunda residência, podendo ter 
ocorrido que, no momento da entrevista, ela tenha sido realizada com algum funcionário da residência, como o caseiro, por exemplo.

Em relação à composição racial, de acordo com o Portal e Observatório sobre Iniquidades em Saúde, ao publicar uma reportagem segundo o Censo de 2010, relata que dos 191 milhões de brasileiros em 2010, 91 milhões se denominaram como brancos, 15 milhões como pretos, 82 milhões como pardos, 2 milhões como amarelos e 817 mil como indígenas. Sendo assim, a população parda e preta maior do que a população branca, com 50,7\% e 47,7\%, respectivamente (DSSBR.ORG, 2012).

Assim, lembrando que o bairro do Porto Frade possui o menor intervalo de pessoas residentes, entre 29 e 182 pessoas, as informações expostas no mapa retrata considerável concentração de renda nesse bairro e segregação racial, já que mesmo somando pardos, amarelos, pretos e indígenas, os mesmos não ultrapassaram a quantidade de brancos no local.

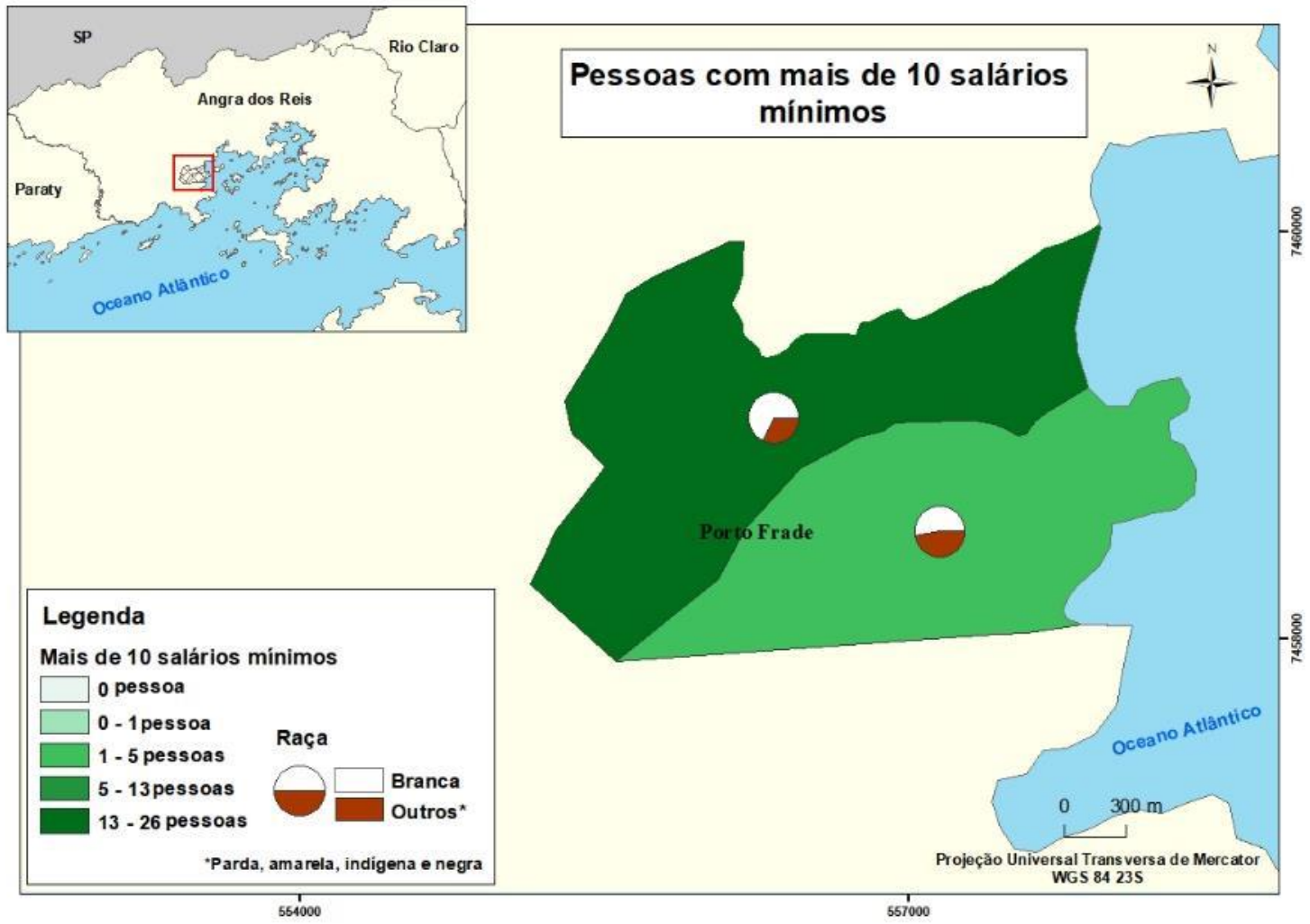

Mapa 03: Número de pessoas com mais de 10 salários mínimos x Raça - Angra dos Reis/RJ.

Fonte: Própria

No bairro do Frade (mapa 04) nota-se que o número de pessoas que ganham mais de 10 salários mínimos é significativamente menor, já a quantidade de pessoas pardas, amarelas, pretas ou indígenas, significativamente maior do que a do Porto Frade. Observa-se que apenas 2 setores possuem de 1 a 5 pessoas com mais de 10 salários mínimos; 8 setores com 1 pessoa; e 4 setores onde ninguém recebe mais de 10 salários mínimos. Destaca-se o Sertãozinho do Frade (último setor mais próximo da mata), com a menor quantidade de brancos e com o segundo maior número de pessoas residentes entre 1040 a 1384. 


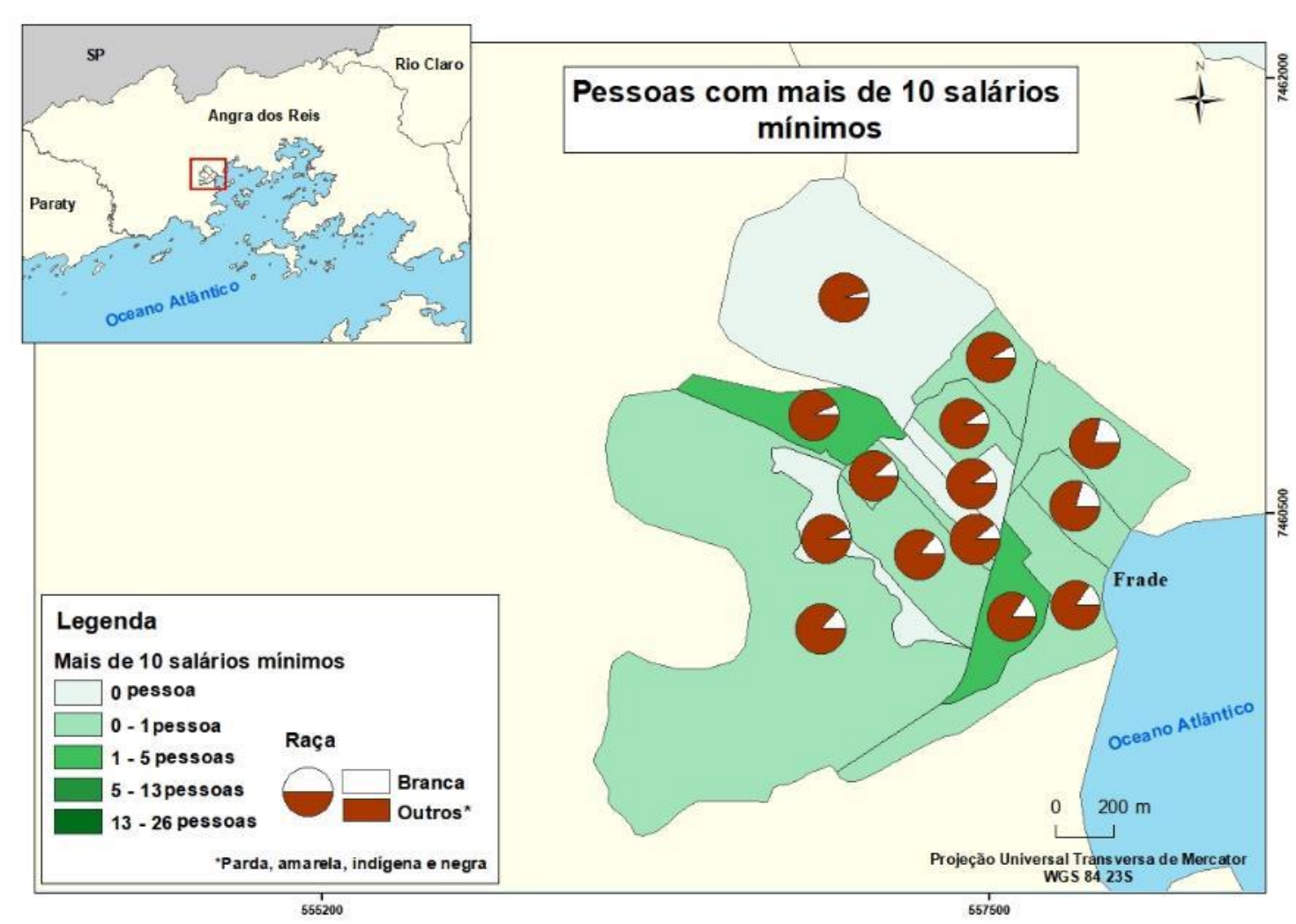

Mapa 04: Número de pessoas com mais de 10 salários mínimos x Raça - Angra dos Reis/RJ.

Fonte: Própria

Os bairros Grataú, Praia do Recife, Gamboa do Bracuí, Santa Rita do Bracuí, Bracuí, Sertão do Bracuí e Itanema são retratados no mapa 05. Evidencia-se 1 setor do bairro Bracuí com maior número de pessoas com mais de 10 salários mínimos (entre 13 e 26 pessoas), onde se localiza partes do empreendimento Porto Marina Bracuhy, como o Porto Bracuhy Imóveis, Hotel Engenho, condomínio do Porto e BR Marinas Bracuhy.

A $3^{\circ}$ classe com 1 a 5 pessoas com mais de 10 salários mínimos abrange o menor setor do Bracuí, onde também se localiza partes do empreendimento Marina Bracuhy como o condomínio Piccola Marina, 1 setor de Santa Rita do Bracuí, Sertão do Bracuí e Itanema onde se encontra o Condomínio Porto Marisco e a Rio Marina Yacht Collection.

Com 0 ou 1 pessoa com mais de 10 salários mínimos encontram-se Gamboa do Bracuí, Ilha do Jorge, Grataú, Praia do Recife, 2 setores de Santa Rita do Bracuí e 2 do bairro Bracuí onde se situa partes do empreendimento Porto Marina Bracuhy e a habitação Morada do Bracuhy.

No que concerne ao número de brancos e outros nos setores, nota-se que os únicos locais onde o número de brancos supera o número de outros é no bairro Grataú, Praia do Recife e dois setores do Bracuí, justamente onde se localiza o empreendimento Porto Marina Bracuhy.

Destaca-se que dos setores do Bracuí, onde se localiza o maior número de pessoas com mais de 10 salários mínimos, encontra-se o segundo menor intervalo de pessoas residentes, entre 182 a 634 pessoas. Já o bairro do Grataú, Praia do Recife e o setor menor do Bracuí possuem o menor número de pessoas residentes entre 29 e 182 pessoas.

Os imóveis ofertados pelo Porto Marina Bracuhy são permitidos em 03 ambientes com valores diferenciados: marina, praia e canal navegável. De acordo com o site da imobiliária Porto Bracuhy Imóveis (2014), uma casa no canal navegável para aluguel de temporada com 05 quartos, sala, escritório, piscina, sauna e academia, o valor é de $\mathrm{R} \$$ 
4.800,00 a diária. Já os valores para a venda variam de $\mathrm{R} \$ 750.000,00$ a acima de $\mathrm{R} \$$ $3.500 .000,00$.

O local também comporta a Marina Bracuhy JL que suporta cerca de 350 embarcações em vaga molhada distribuídas em 9 decks (MARINABRACUHYANGRA, 2016). Assim, também se verifica que para manter gastos com imóveis do valor acima citados, além de valores com condomínio e possíveis embarcações, é necessário, ter renda superior a $\mathrm{R} \$ 5.100,00$.

Assim, também se evidencia substancial concentração de renda nesse empreendimento e segregação racial, principalmente nos dois setores menores, com mais da metade de seus moradores constituídos por pessoas brancas.

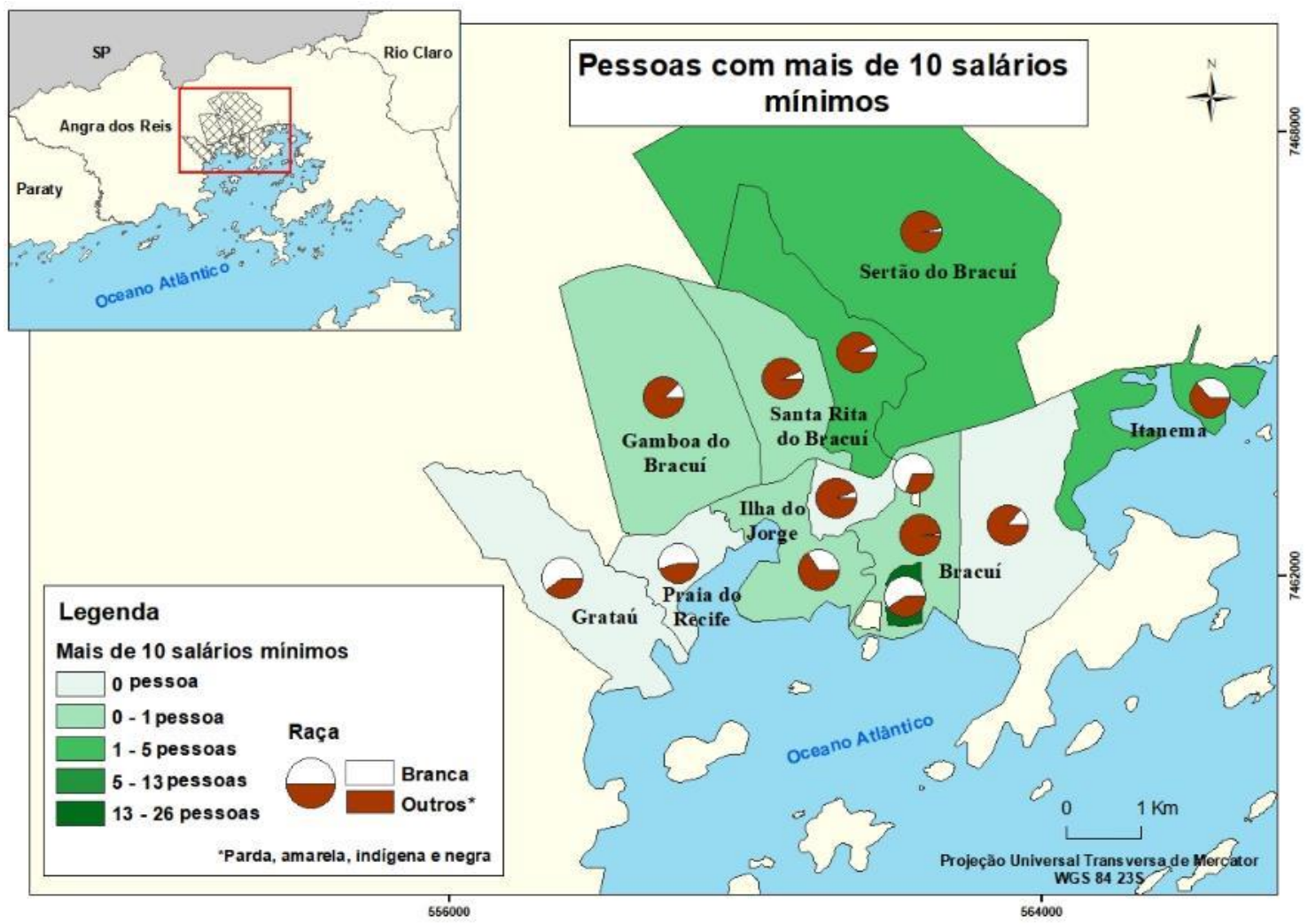

Mapa 05: Número de pessoas com mais de 10 salários mínimos x Raça - Angra dos Reis/RJ.

Fonte: Própria

Os mapas abaixo (mapas 06, 07 e 08) retratam os setores onde existe maior número de pessoas com $1 / 2$ a 1 salário mínimo, assim como, se há maior número de brancos ou outros nos respectivos setores.

O mapa 06 concentra-se no bairro Porto Frade, local de instalação do empreendimento turístico Porto Frade. Constata-se que nos dois setores existem 2 a 10 pessoas com $1 / 2$ a 1 salário mínimo e a maioria dos seus moradores de cor branca. Faz-se necessário recordar os altos valores dos imóveis nesse bairro, por isso, as pessoas que relataram receber de $1 / 2$ a 1 salário mínimo, possivelmente, não são moradores locais, contudo, caso sejam, podem ser prestadores de serviço dos condôminos ou do empreendimento. 


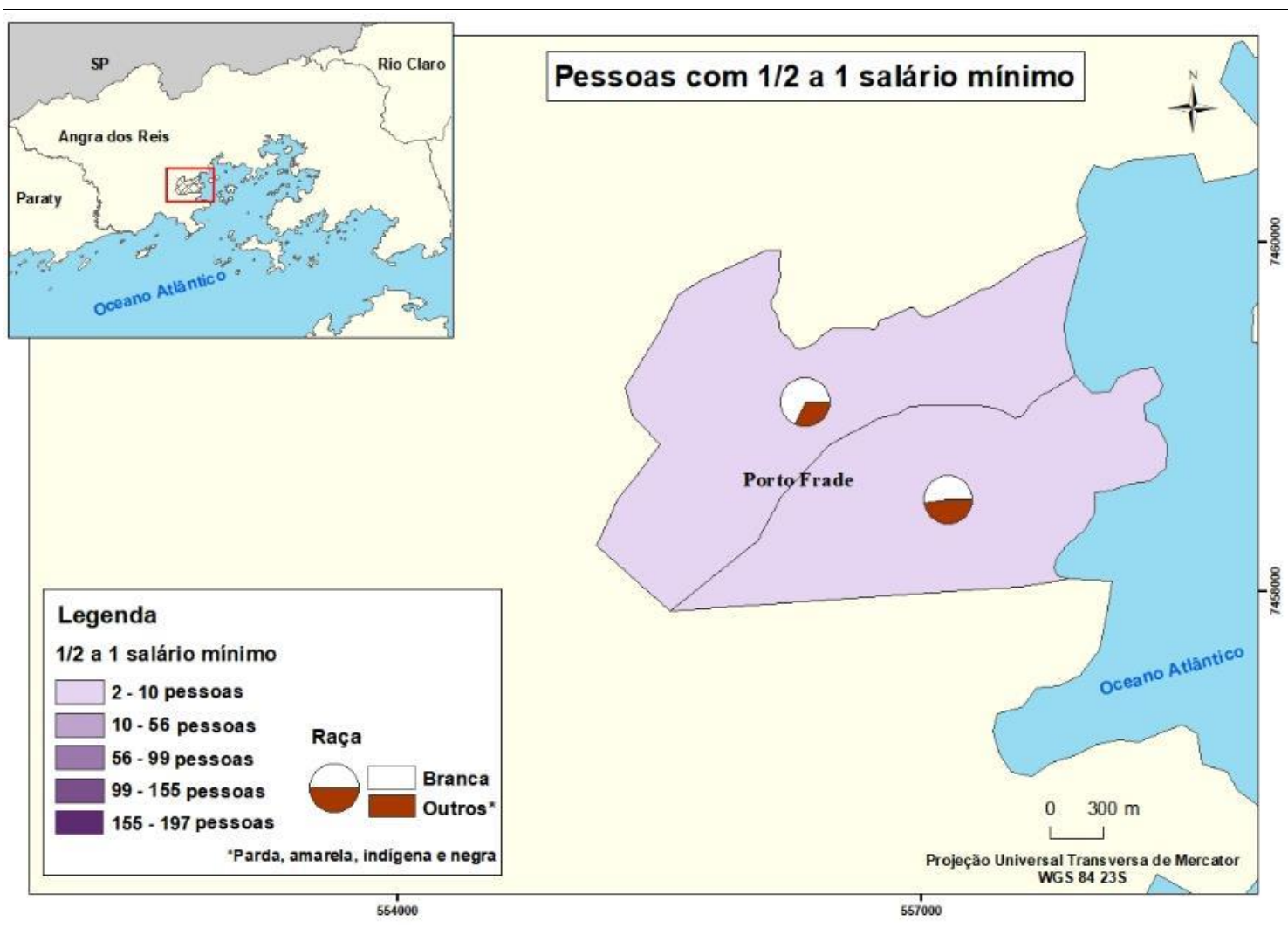

Mapa 06: Número de pessoas com $1 \frac{1}{2}$ a 1 salário mínimo x Raça - Angra dos Reis/RJ. Fonte:

Própria

O bairro do Frade representado no mapa 07 demonstra que dos 14 setores do bairro, 6 deles possuem de 99 a 155 pessoas que recebem $1 / 2$ a 1 salário mínimo, 5 setores com 56 a 99 pessoas com $1 / 2$ a 1 salário mínimo e 3 setores com 10 a 56 pessoas que recebem $1 / 2$ a 1 salário mínimo. Nota-se que no tocante racial, todos os setores o número de outros (pardos, amarelos, indígenas e pretos) é significativamente maior do que a quantidade de brancos.

Novamente, destacam-se os dois últimos setores a noroeste, pois possuem o maior número de pessoas residentes desse bairro, entre 1040 a 1384. Assim como, também se evidenciam pelo número de pessoas que recebem de $1 / 2$ a 1 salário mínimo como exposto acima e, por possuírem, juntamente, com outro setor à esquerda, maior quantidade de pessoas da raça parda, amarela, indígena e preta (outros) do que brancos em relação aos demais setores do bairro. 


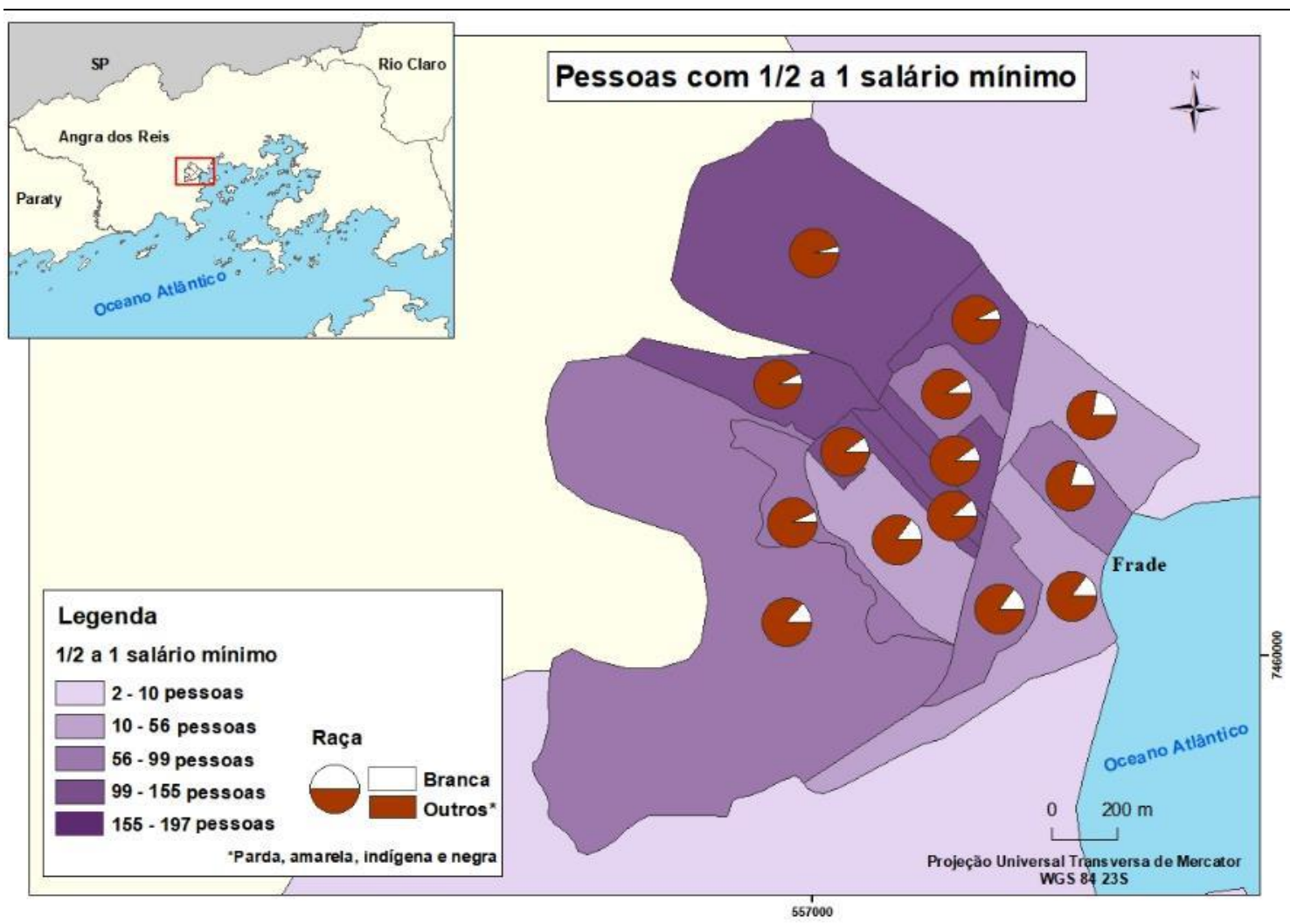

Mapa 07: Número de pessoas com 1/2 a 1 salário mínimo x Raça - Angra dos Reis/RJ. Fonte: Própria

O mapa 08 subsequente representa os bairros Grataú, Praia do Recife, Gamboa do Bracuí, Ilha do Jorge, Santa Rita do Bracuí, Bracuí, Sertão do Bracuí e Itanema. Desses ressaltam-se o bairro Sertão do Bracuí e 1 setor do bairro Bracuí onde se localiza partes do empreendimento Porto Marina Bracuhy e a habitação social Morada do Bracuí com 155 a 197 pessoas com $1 / 2$ a 1 salário mínimo. Após, destaca-se o bairro Santa Rita do Bracuí e 1 setor do bairro Bracuí com 155 a 56 pessoas com 1/2 a 1 salário mínimo e com o menor número de pessoas (56 a 2) que recebem o mesmo valor, tem-se os bairros Gamboa do Bracuí, Ilha do Jorge, Grataú, Praia do Recife, Itanema e dois setores do Bracuí onde se instalam partes do empreendimento Porto Marina Bracuhy.

É notório como o número de pessoas brancas cresce nos setores conforme o número de pessoas que recebe de 1/2 a 1 salário mínimo diminui. Deste modo, nos bairros ou setores onde há o menor número de pessoas com $1 / 2$ a 1 salário mínimo também é onde se localizam o maior número de pessoas brancas, vide bairro Grataú, Praia do Recife, os dois setores menores do Bracuí onde se situam partes do empreendimento e Itanema. Assim como, nos dois locais onde se agrupam maior número de pessoas que recebem de $1 / 2$ a 1 salário mínimo como relatado acima, é justamente, onde se localizam maior quantidade de pessoas das raças representadas por outros. Percebe-se que nesses dois setores falta pouco para o gráfico ser totalmente preenchido pela cor marrom. Os mesmos setores também se destacam por possuir maior número de pessoas residentes entre 1384 a 2165 pessoas. 


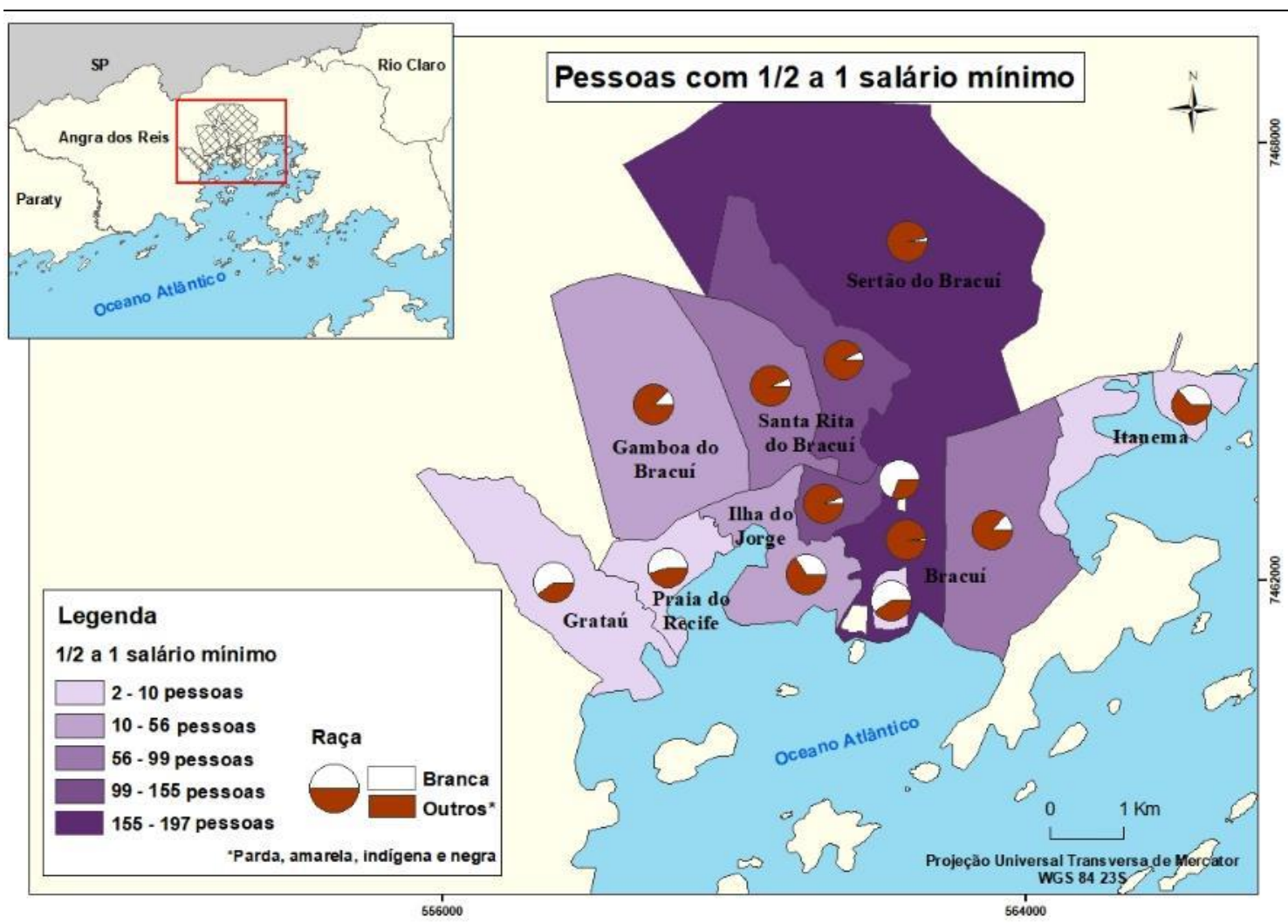

Mapa 08: Número de pessoas com 1⁄2 a 1 salário mínimo x Raça - Angra dos Reis/RJ. Fonte:

Própria

Em suma, identifica-se que nos setores onde há pessoas com menor poder aquisitivo é exatamente onde se agrupam maior número de pessoas da raça parda, amarela, indígena e preta. Assim como, o maior número de pessoas residentes. Logo, evidencia-se, a segregação econômica por raça sofrida nesses locais.

O mapa 09 abaixo demonstra quais são os setores dentre os analisados que são classificados como aglomerados subnormais, que segundo o IBGE (2010) são aqueles que ao longo do país são denominados por diversos nomes, como favela, comunidade, grotão, vila, mocambo e outros, caracterizado como:

conjunto constituído por 51 ou mais unidades habitacionais caracterizadas por ausência de título de propriedade e pelo menos uma das características abaixo:

- irregularidade das vias de circulação e do tamanho e forma dos lotes e/ou - carência de serviços públicos essenciais (como coleta de lixo, rede de esgoto, rede de água, energia elétrica e iluminação pública) (IBGE, 2010, p. 3).

Assim, dos 14 setores que constituem o bairro do Frade, 10 foram caracterizados como aglomerados subnormais, além do bairro Gamboa do Bracuí, Santa Rita do Bracuí e 01 setor do bairro Bracuí. 


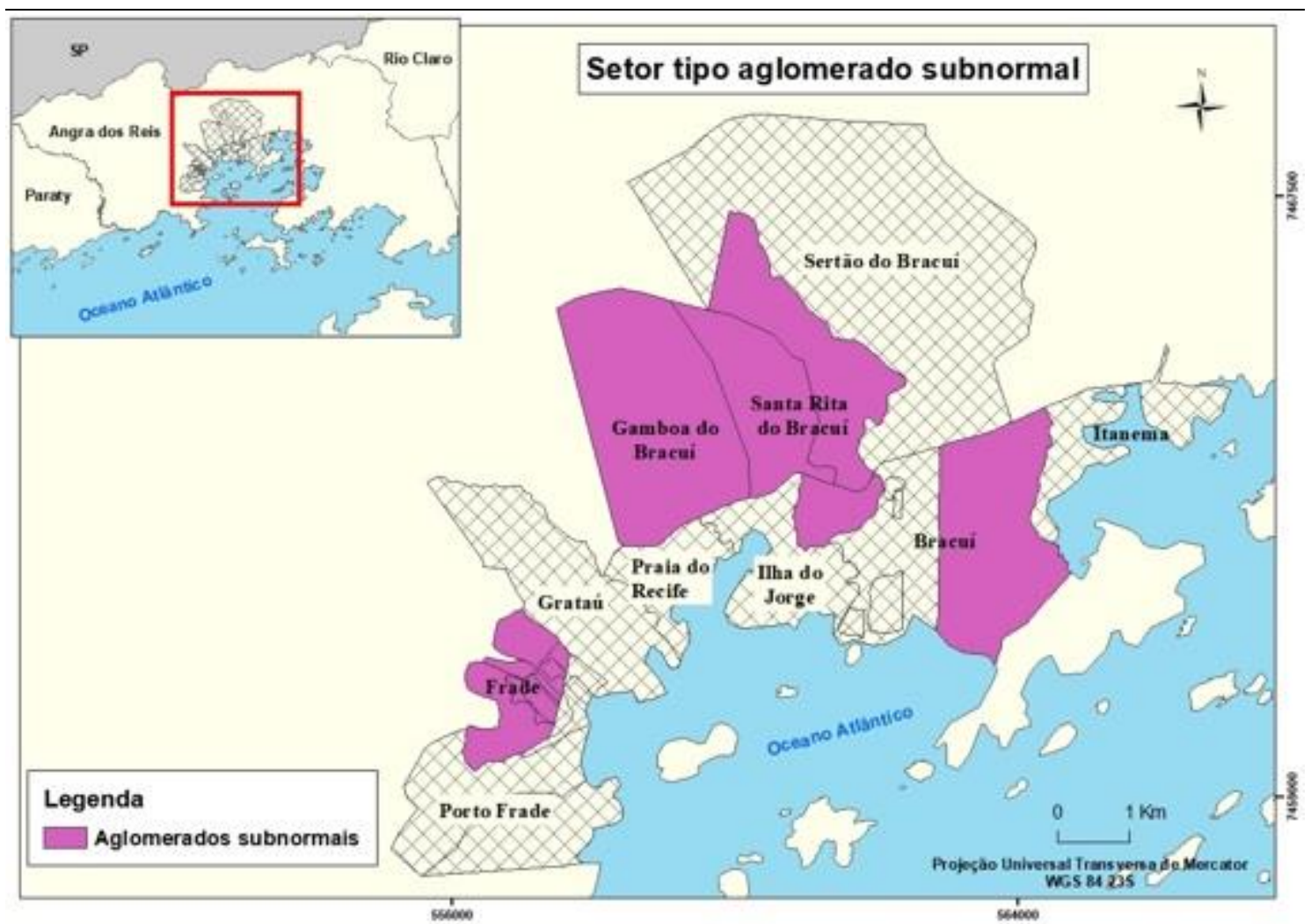

Mapa 09: Setor tipo aglomerado subnormal - Angra dos Reis/RJ. Fonte: Própria

Por meio das análises realizadas, é perceptível que os empreendimentos Porto Frade e Porto Marina Bracuhy, beneficiaram-se do projeto Turis para sua implantação no local. Assim como, o surgimento dos demais bairros, especialmente do Frade e do Bracuí, apenas ocorreu após a implantação dos referidos empreendimentos. Por conseguinte, o bairro Porto Frade e a área em torno do canal navegável do empreendimento Porto Marina Bracuhy cresceram de forma organizada, com casas de alto padrão, ruas pavimentadas e adequado serviços de saneamento básico e de segurança, alguns deles ofertados de forma privativa, como por meio da outorga d'água conseguida pelos empreendimentos. E consequentemente, seus moradores/visitantes possuem poder aquisitivo consideravelmente maior do que nos bairros próximos.

No que diz respeito aos bairros vizinhos, principalmente o do Frade, estes cresceram de forma desorganizada, com carência de infraestrutura urbana e saneamento básico, além de possuírem renda significativamente inferior aos dos moradores dos empreendimentos. Tal fato pode ser observado pelo número de aglomerados subnormais existentes na área de estudo.

Além da forte concentração de renda observada pelos mapas temáticos nos empreendimentos, também é notório o processo de periferização de alguns bairros, como o do Frade. Nesses locais, os moradores são marginalizados principalmente por fatores econômicos e raciais, já que através das análises dos mapas, é notável como a população branca concentra-se nas áreas mais ricas e de fácil acesso. Enquanto parte considerável da população classificada como outros (pardos, amarelos, indígenas e pretos) habitam locais mais simples, com deficiência nos serviços de saneamento básico, próximos a morros e encostas, e outros fatores. Determinados setores do bairro Frade e do bairro Santa Rita do Bracuí, necessitam de especial atenção por reunirem características alarmantes por serem classificados como aglomerados subnormais e possuírem considerável número de pessoas com $1 \frac{1}{2}$ a 1 salário mínimo. 
Outro local que merece destaque é o bairro do Grataú devido à retirada de áreas de floresta e aterro de manguezais. Propriedade essa localizada em área urbana que há décadas não cumpre sua função social, sendo denominada de área de interesse turístico pela lei de zoneamento do município em $2009^{2}$. Assim, nota-se como o próprio instrumento de ordenamento territorial de uma localidade pode ser um fator de fomento ao processo de segregação socioespacial, reservando as áreas mais nobres da cidade para iniciativa privada, nesse caso, para o capital imobiliário.

Enquanto isso, bairros como o do Frade, localizado ao lado do Grataú, e outros mais afastados, como Santa Rita do Bracuí, Bracuí e outros, crescem de forma desordenada e com carência de infraestrutura básica, fatores esses, que também expõem os moradores a possíveis problemas socioambientais, como enchentes e deslizamento de terra. Logo, configura-se assim, o efeito em cascata decorrente da apropriação do espaço evidenciando a segregação socioespacial como retratado na figura 06.

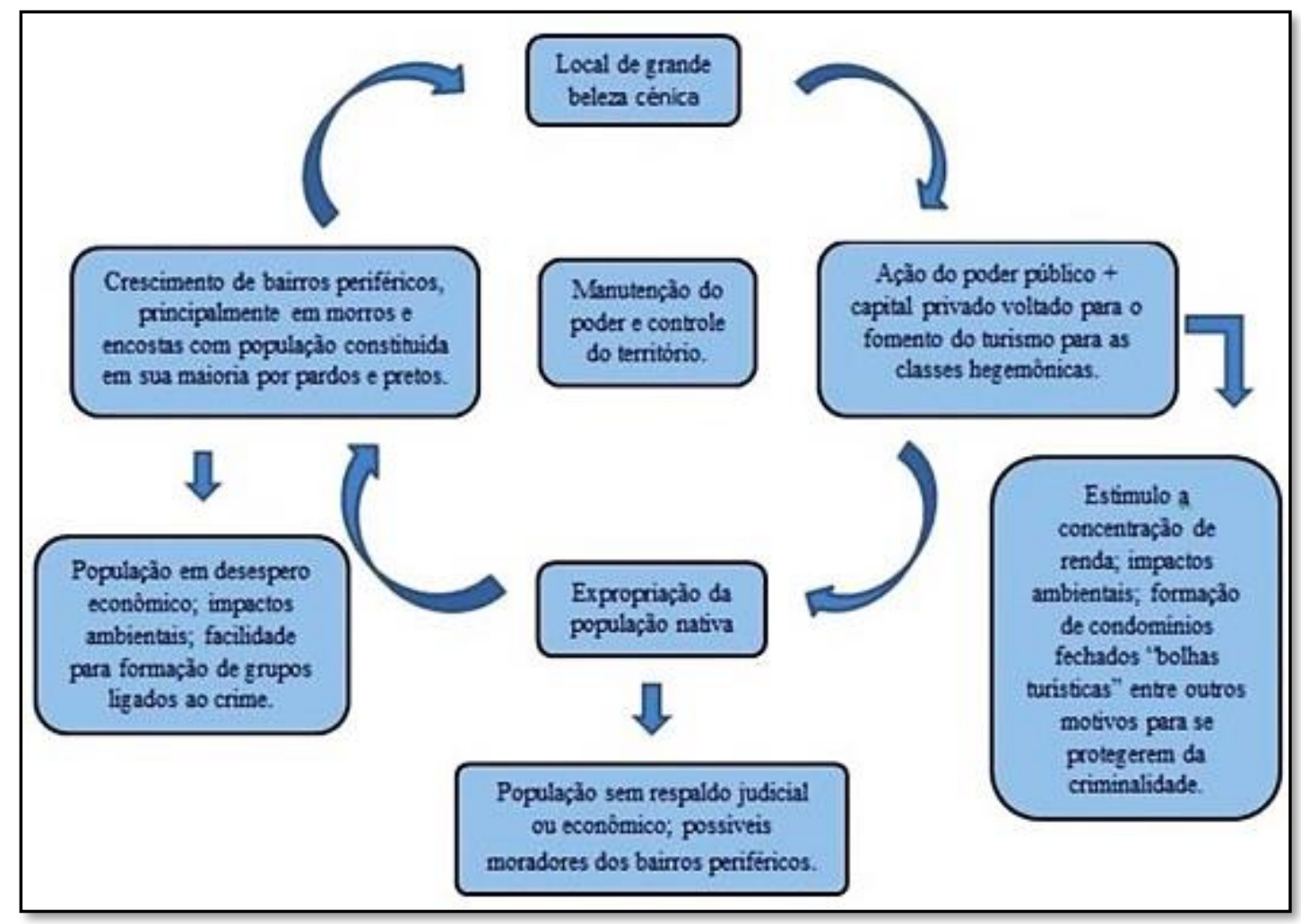

Figura 06: Fluxograma do processo de segregação socioespacial observado no estudo. Fonte:

$$
\text { Própria }
$$

Assim, a partir do referencial teórico e da análise dos mapas temáticos foi possível identificar o processo de segregação socioespacial que ocorreu a partir da implantação desses empreendimentos turísticos-imobiliários.

Em relação ao desenvolvimento do turismo dito "de luxo" o efeito em cascata se dá a partir da apropriação de um local de grande beleza cênica, de forma a expropriar a população que habitava a localidade, possivelmente uma comunidade tradicional sem respaldo judicial ou econômico. Essa apropriação ocorre por meio de ações do poder público associada ao capital privado que atuam de maneira a fomentar o turismo voltado para as classes hegemônicas, contribuindo para a concentração de renda, especulação imobiliária, impactos ambientais como supressão da vegetação, abertura de canais navegáveis, ocupação em áreas de proteção permanente e outros.

Esta população expropriada, afastada do seu modo de vida, soma-se a quantidade de moradores de bairros periféricos, e em uma região com o relevo acidentado como a 
Costa Verde, é comum que esses bairros formem-se em morros e encostas, que associado a outros eventos, como chuvas intensas, podem acarretar em novos impactos socioambientais como deslizamento de terra, enchentes e outros. E no que se refere a Angra dos Reis, como evidenciado por meio da análise dos mapas, esta população constitui-se em sua maioria de pardos e pretos.

Esse processo de segregação socioespacial organiza o território de forma a manter o poder e o controle sobre o mesmo.

\section{Considerações Finais}

O turismo como uma das atividades econômicas de uma localidade, pode ser um fator estratégico para o desenvolvimento local, na medida em que visa à conservação e valorização do patrimônio natural, histórico-cultural, e a oferta de empregos diretos e indiretos. Para tanto, é necessário um planejamento holístico da atividade com a articulação do poder público, do capital privado e essencialmente da comunidade receptora, que será a principal agente passiva dos impactos dessa atividade.

Contudo, o que se observa em Angra dos Reis, é uma cidade com expressivo potencial para o desenvolvimento do turismo, por meio de suas inúmeras belezas naturais como ilhas, praias, cachoeiras, Mata Atlântica e outros, mas onde o turismo que se desenvolveu no local ocorreu por meio de parceria público-privada, omitindo a população local.

O turismo na localidade consolidou-se com base em exclusão, representados pelos complexos turísticos-imobiliários, que muitas vezes reúnem resorts e/ou hotéis de alto padrão, condomínios de luxo, marinas, campo de golfes, e outros serviços voltados para o público de maior poder aquisitivo.

Tais complexos ocupam grandes extensões de terra localizados nas áreas nobres da cidade, como os empreendimentos Porto Frade e Porto Marina Bracuhy, no presente trabalho analisados. Esse modo de apropriação do espaço contribui para o processo de periferização e segregação socioespacial na localidade, pois próximos a esses empreendimentos, formam-se bairros periféricos, com considerável adensamento populacional, como exemplo, o bairro do Frade, além da negligência na oferta de serviços de infraestrutura básica e direitos sociais, e o crescente problema de segurança pública.

A segregação socioespacial verificada na área de estudo mostrou-se expressiva em relação ao número de salários mínimos recebidos pelos moradores nesses bairros e pela sua composição racial, sendo observado quantidade significativa de moradores que recebem entre $1 / 2$ a 1 salário mínimo e a maioria de seus habitantes serem pardos, amarelos, indígenas ou pretos. Fato que se configura de modo inverso na maioria dos setores dos empreendimentos, já que boa parte de seus habitantes é branca e recebe mais de 10 salários mínimos.

Muitas vezes esses bairros são formados pela própria comunidade tradicional que foi expropriada de suas terras para dar lugar aos projetos turísticos e vão abrigar-se em locais menos nobres, ou seja, que demandem pouco poder de compra, como morros, encostas e áreas sujeitas a alagamentos e enchentes, que podem representar riscos a manutenção da vida, como tão comumente evidenciado nos recorrentes casos de desastres naturais no município.

Também ao observar o mapa do zoneamento municipal de Angra dos Reis, notase que nos bairros mais próximos aos empreendimentos são poucas as áreas consideradas como zonas de interesse turístico, que possam ofertar equipamentos e serviços aos visitantes. Existem apenas 03 próximas ao empreendimento Porto Frade e nenhuma próxima ao Porto Marina Bracuhy, assim como, não cresceram as áreas comerciais. 
Destaca-se que os empreendimentos instalaram-se no local desde meados da década de 1970, ou seja, há mais de 40 anos, intervalo de tempo considerável para a população envolver-se com o turismo.

Logo, o município de Angra dos Reis na posição de um dos 65 destinos indutores do turismo no Brasil, necessita investir na potencialidade de outros segmentos turísticos locais, e não apenas no segmento sol e praia, voltado para o turismo de segundas residências. Uma oportunidade seria o bairro Grataú com forte potencial para o turismo histórico-cultural. Todavia, esse bairro deve ser observado de maneira meticulosa, pois caracterizado como Zona de Interesse Turístico 1 no zoneamento municipal, isto é, local capaz de absorver grandes estruturas hoteleiras. Entretanto, deve-se evitar que o desenvolvimento no local ocorra de forma a segregar outros moradores, como identificado nos empreendimentos vizinhos.

É imprescindível que a comunidade local tenha a opção de se envolver com o turismo e possa fazer dele uma opção de renda, de lazer e de instrumento para uma maior qualidade de vida, através, principalmente, de políticas públicas que inclua e incentive a participação local.

Assim, com as informações apresentadas neste estudo, é notável o poder do uso da Geoinformação, tendo os SIGs como ferramentas de auxílio para o armazenamento, manipulação, atualização e exposição de dados de maneira simples e precisa, além de recursos visuais como as fotografias aéreas, e o apoio de programas gratuitos que fornecem dados georreferenciados, tais como o Google Earth, imprescindíveis para a vigilância, controle, planejamento e gestão de atividades, sejam elas ligadas ao turismo, ao meio ambiente ou ao meio urbano.

Logo, contribuem também, para a tomada de decisão e para o direcionamento de políticas públicas para os locais que apresentem maior vulnerabilidade socioambiental e auxilie no processo de autonomia da população autóctone, aumentando seu poder de autocriação e formação de uma imaginação social instituinte embasada nos preceitos da sustentabilidade com justiça social e ambiental.

\section{Notas}

1 - Tais informações podem ser conferidas no artigo publicado em: <http://periodicos.uem.br/ojs/index.php/BolGeogr/article/view/32732/> Acesso em: 05/12/2018

2 - PREFEITURADEANGRADOSREIS. Zoneamento municipal de Angra dos Reis. Disponível em: <http://www.angra.rj.gov.br/downloads/SMA/LEI\%202091-2009-zoneamento\%20do\%20municipio.pdf /> Acesso em: 13/01/16.

\section{Referências}

ABREU, C.V. Urbanização, apropriação do espaço, conflitos e turismo: um estudo de caso de Angra dos Reis. 2005. 163 f. Dissertação (Mestrado em Arquitetura e Urbanismo) - Centro Tecnólogo, Universidade Federal Fluminense, Niterói. 2005. Disponível em < http://www.dominiopublico.gov.br/pesquisa/DetalheObraForm.do?select_action\&co_obra=179 936 /> Acesso em 15/08/15. ALERJ. Disponível em:

<http://alerjln1.alerj.rj.gov.br/constfed.nsf/16adba33b2e5149e032568f60071600f/62e3ee4d23ca 92ca0325656200708dde?OpenDocument/> Acesso em: 23/10/15.

ANGRANEWS. Disponível em: < http://angranews.com.br/moradores-do-condominio-moradado-bracuhy-realizam-protesto /> Acesso em: 15/11/16. 
BRASIL. Ministério do Turismo. Código de Ética Mundial para o Turismo. Brasília, DF, 2015. Disponível em: <http://www.turismo.gov.br/programas/5049-codigo-de-etica.html/> Acesso em: 05/11/15.

CÂMARA, G; DAVIS, C; MONTEREIRO, A.M.V. Introdução à Ciência da Geoinformação. São José dos Campos: INPE, 2001. p. 345. Disponível em: < http://mtcm12.sid.inpe.br/col/sid.inpe.br/sergio/2004/04.22.07.43/doc/publicacao.pdf /> Acesso em: $13 / 11 / 2015$.

CASTORIADIS, C. A Instituição Imaginária da Sociedade. Rio de Janeiro: Paz e Terra, 1982. P 418.

CORREA, R.L. O Espaço Urbano. São Paulo: ÁTICA, 1989. p. 94.

CPDA-UFRRJ. Relatório final - Conflitos por terra e repressão no campo no estado do rio de janeiro (1946-1988). Rio de Janeiro, 2015. 959 p.

DSSBR. Disponível em: <http://dssbr.org/site/2012/01/a-nova-composicao-racial-brasileirasegundo-o-censo-2010/> Acesso em: 10/03/16.

ELETRONUCLEAR. Disponível em: < http://www.eletronuclear.gov.br/hotsites/eia/v02_06_diagnostico.html\#632

/> Acesso em: 28/11/15.

FITZ, P. R. Geoprocessamento sem complicação. São Paulo: Oficina de textos, 2008.

GLOBO. Disponível em: <http://g1.globo.com/rio-de-janeiro/noticia/2013/01/no-sul-do-rjforte-chuva-deixa-desalojados-em-angra-dos-reis.html/> Acesso em: 29/09/15.

GÓIS, M.P.F. A Territorialização do Turismo em Angra dos Reis - RJ. 2009. 84f. Monografia (Especialização em Políticas Territoriais) - Instituto de Geografia, Universidade do Estado do Rio de Janeiro, Rio de Janeiro, 2009.

IBGE. Aglomerados subnormais informações territoriais. Disponível em: < http://www.ibge.gov.br/home/presidencia/noticias/imprensa/ppts/000000151648112020134801 05748802.pdf /> Acesso em: 04/03/16.

IBGE. Base de informações do Censo Demográfico 2010: Resultados do Universo por setor censitário. Rio de Janeiro, 2011. Disponível em:

<http://censo2010.ibge.gov.br/resultados.html/> Acesso em: 22/08/15.

MAPADECULTURA. Disponível em: < http://mapadecultura.rj.gov.br/manchete/quilombosanta-rita-do-bracui /> Acesso em: 04/03/16.

MARINABRACUHYANGRA. Disponível em: < http://www.marinabracuhyangra.com.br/> Acesso em: 25/02/16.

SILVA, J. X.; ZAIDAN, R.T. Geoprocessamento \& Análise Ambiental: aplicações. Rio de Janeiro: Bertrand Brasil, 2004.

SANTOS, M. A Urbanização Brasileira. São Paulo: HUCITEC, 1993. p. 174

UOL. Disponível em: <http://economia.uol.com.br/noticias/redacao/2015/09/30/feira-em-saopaulo-tem-iate-de-luxo-e-barco-a-preco-de-carro-popular.htm/> Acesso em: 02/03/16.

ZAPIMÓVEIS. Disponível em: <http://www.zapimoveis.com.br/venda/casas-decondominio/rj+angra-dos-reis++frade/> Acesso em: 02/03/16. 